\title{
A SZERVEZET INTERPRETATÍV MEGKÖZELÍTÉSE
}

Az interpretatív elmélet a fóáramot jelentő funkcionalista szervezetközelítések egyik legfontosabb alternatívája. Bár a szerző lényeges célnak tekinti, hogy a tudományos célú szervezetvizsgálatokban hazánkban is szemléletváltás következzék be, nagy veszélynek tartja ezen alternatív megközelítések félreértését. Jelen tanulmány fó célja ezért az interpretatív szervezetközelítés tudományelméleti alapjainak megvilágítása, illetve illusztratív példákon keresztül az elmélet szervezeti relevanciájának bemutatása, és a megközelítés hozzákötése a kvalitatív szervezetkutatáshoz.

\section{Kovács Sándor Tanár Úr emlékére, mély hálával}

„A gondolkodás megteremti a világot, majd ezt mondja: 'Nem én voltam!'.”

David Bohm

\begin{abstract}
„Akkor értünk meg valamit, ha azt úgy alkalmaztuk magunkra, hogy közben valamilyen választ fedeztünk fel benne a mi kérdéseinkre... Az, hogy egy szöveg megszólal, csak a ma hozzá intézett kérdéseinknek köszönhető."
\end{abstract}

Jean Grondin

„A megismerés: az átellenben álló szemlélése által a megismerö elött feltárul a lényeg."

Martin Buber

Főként európai szervezetkutatói körökben már hosszú évek óta komoly kritikák érik a szervezet „,bevett”, hagyományos közelítésmódjait - a funkcionalista szervezetfelfogást, a pozitivista kutatói alapállást. Ez nemcsak a nemzetközi publikációkból látható, hanem a tudományos konferenciák felhívásait és témáit tekintve, az itt propagált megközelítésmódokat tanulmányozva is. A kontinens északibb felén és az Egyesült Királyságban ma már a „mainstream”-től eltérő számít kívánatosnak, sőt úgy tűnhet, hogy az interpretatív, konstruktivista, kritikai, posztmodern, posztstukturalista vagy feminista szemléletmód jelenti az „új főáramot”.

Bár jelentős lemaradásban vagyunk, az utóbbi néhány évben mintha Magyarországon is egyre többen keresnék a funkcionalista-pozitivista paradigma alternatíváit: született néhány interpretatív, posztmodern, kritikai és feminista alapállású, kvalitatív módszertant (is) alkalmazó doktori disszertáció, szakcikk, és nappali szakdolgozat. Persze továbbra is igaz, hogy a „hazai üzleti tudományos kutatásokra ránehezedik a kvantitatív fóáram" (Radácsi, 2003:7.), de remélhetjük, hogy - ha lassan is és csak szórványosan - a helyzet azért változik. Míg PhD hallgatóként 6-8 éve még a szakmai tekintélyszemélyek alapvető kétségeivel és bírálataival szemben - de szerencsénkre Kovács Sándor Tanár Úr bátorítását és szakmai támogatását mindvégig élvezve - tartottunk ki saját, „,nem-funkcionalista” alapállásunk mellett, ma már előfordul, hogy egy-egy $\mathrm{PhD}$ tézis-védésen - az egyébként „megrögzött funkcionalista”-ként számon tartott műhely vezető oktatója is - egyedi esetek kvalitatív vizsgálatára bíztatja a jelöltet. Eközben, saját bevallásuk szerint a Szervezetelméletek c. kurzusok hatására ${ }^{1}$, a doktori és nappali hallgatók közül - önértelmezésük szerint - egyre többen válnak ,interpretatívvá”, „kritikaivá” vagy „radikális humanistává”, de minimum „,anti-funkcionalistává”; bármit jelentsenek is ezek a fogalmak.

Márpedig egyáltalán nem mindegy, hogy mit jelentenek! Megint csak saját tapasztalataimra hivatkozva: túl azon, hogy a hallgatók egy részénél ez mintha csak egyfajta „divat” lenne, úgy látom, hogy a komolyan vett próbálkozásoknál is sokszor lényeges elméleti-koncepcionális vagy módszertani félreértésekre, és ezek hátterében, alapvető tudományfilozófiai tévedésekre épül ez az „alternatív közelítésmód”. S ezzel nemcsak az a gond, hogy az így megfogalmazott „alternatíváról” végül is felsejlik annak nagyon is funkcionalista alaptermészete (amely alapállás egyébként, szögezzük le, önmagában teljesen adekvát lehet). A fő probléma az, 
hogy eközben maga a képviselni kívánt új eszmerendszer is elhasználódik, még mielőtt ténylegesen megfogalmazták volna, s kiderülhetett volna valódi lényege és relevanciája. Mindaz, ami eredendően éppen a funkcionalizmus szervezetelméleti-tudományelméleti alternatíváját jelentené, a menedzsmentdivatok mintájára (pl. Kieser, 1996) könnyen „kimegy a divatból”, vagy puszta látszattá, retorikai fogássá válva integrálódik a funkcionalizmusba.

A következőkben szeretném valamelyest tisztázni és a „helyére tenni” a fenti koncepciók némelyikét. Fő fókuszban a szervezet interpretatív megközelítése áll. Elsősorban a tudomány- és szervezetelméleti alapok megvilágítása a célom, e szervezetközelítés mögöttes előfeltevéseinek megfogalmazása (és nem pl. a kapcsolódó kutatások áttekintése). Az előzőekből már látszik, hogy e tanulmányt elsősorban a tudományos célközönségnek szántam - szervezetkutatóknak, szervezetelméleti szakembereknek és doktori hallgatóknak, illetve egyetemi oktatóknak és hallgatóknak, azt remélve, hogy gondolataimmal segíthetem a szervezetek alaptermészetéről szóló tudományos párbeszéd élénkülését, és a szilárd elméleti talajon álló kvalitatív szervezetkutatások terjedését. De gyakorlat és elmélet merev szétválasztását elhibázottnak tartanám, hisz' különféle szakmai szerepeimben (oktató, kutató, szervezetfejlesztő tanácsadó) az integráció megvalósítására törekszem magam is. Meggyőződésem, hogy az interpretatív szervezetközelítés is csak akkor és annyiban kezd el élni, amikor és amennyiben ,a 'szuper-intellektuális elméletet' elkezdjük használatba venni a gyakorlati munkában, így a szervezetkutatásban, szervezeti tanácsadásban vagy akciókutatásban”². Bár ez egy alapvetően elméleti cikk, fontos a gyakorlati relevancia is (pl. az interpretatív-kvalitatív szervezetkutatásról szóló részt).

Lényeges jeleznem azt is, hogy mi nem célom: egyrészt nincs szándékomban érvelni az interpretatív megközelítés, a szubjektivista alapállás vagy a kvalitatív szemléletű kutatás létjogosultsága mellett; hanem magától értetődőként kezelem. Másrészt, ezek fölényét sem állítom, hiszen úgy vélem, a más paradigmák talaján álló más szervezetelméletek és kutatási filozófiák is egyaránt létjogosultak. De tudnunk kell az alternatívákról, és tudatosak kell, legyünk akkor, amikor választunk közöttük, belátva azt is, hogy mindig választunk.

Először a tudományfilozófiai alapokról és a szervezetelmélet episztemikus jellegéről (paradigmafüggőségéről) lesz szó. A szervezetelméleti paradigmák Burrell és Morgan által leírt rendszerezése kapcsán különös hangsúllyal tárgyalom a mátrix két dimenziójának jelentését, mert úgy vélem, az alapvető félreértések innen fakadnak. Ezt a ma is dominánsnak tekinthető funkcionalista paradigma kritikája és az interpretatív válaszok összefoglalása követi. Mindezek pedig megalapozzák a tanulmány fó fókuszát jelentő interpretatív szervezetközelítés elmélyültebb tárgyalását. Ezután egy kiemelt fogalomról a „megértés”-ről, s ennek szervezeti jelentőségéről szólok, legvégül pedig az interpretatív-kvalitatív szervezetkutatás néhány lényeges ismérvéről ${ }^{3}$.

A bevezetésben még egy, távolról sem mellékes mozzanat: az interpretatív megközelítéshez hűen kiemelten fontos tudatában lennem és explicit módon is megfogalmaznom, hogy amit e tanulmányban az interpretatív szervezetközelítésről kifejtek, maga is „egy lehetséges" értelmezés - az enyém. Nem is tud más lenni. De a cikk jelentése már nemcsak tőlem - a cikk szerzőjétől - függ, hanem mindazoktól a jelentést konstruáló jelentéshorizontoktól, melyek itt és most mozgásba jönnek, az írói szándék és az olvasói motívum e jelentést konstruáló összjátékában. Ilyen jelentéshorizontok például: 1) a (tudomány)elméleti és (tudomány)filozófiai gyökerek - szerzők és műveik, melyek alakították és folyamatosan alakítják, 2) saját (szerzői) megértésem, vagyis azt, hogy mi az én olvasatom e témáról, azaz a szervezet interpretatív megközelítéséről. Ez viszont értelemszerűen függ nemcsak, 3) előképzettségemtől és olvasottságomtól, hanem 4) személyes indíttatásomtól és a téma iránti fogékonnyá válásomtól is. Vagyis attól, hogy mennyire tudom jól ellátni az alapvető hermeneutikai feladatot: hogy a lehető legközelebb jussak saját témám belső, rejtekező - és teljességgel soha meg nem ragadható - „leglényegéhez” vagy „lelkéhez”; - jelen esetben az interpretatív közelítés gyökeréhez. De e cikk jelentése és ereje függ, 5) a retorikai dimenziótól is attól, hogy előadásmódom és érvelésem révén mennyire sikerül e lényegi jelentéstartalmat helyesen megragadnom és „lefordítanom”, tehát szavakba öntenem, a mindenkori Olvasó számára. Eddig az én oldalam. Természetesen ahhoz, hogy a leírt szó találkozhasson az Olvasó jelentésvilágával, 6) neki is el kell végeznie a hermeneutikai feladatot, azaz törekednie kell a „helyes” megértésre, ami természetesen függ, 7) előképzettségétől, általános indíttatásától és aktuális befogadókészségétől (például, hogy milyen célból olvassa e tanulmányt, hogy általa milyen - explicit vagy implicit - kérdéseire keresi a választ). Ez utóbbi az Olvasó értelmező- és jelentést konstruáló ereje. Azonban sem a tanulmány szerzője, sem Olvasója - s így maga a tanulmány jelentése - sem függetlenítheti magát a, 8) közvetlen és 9) a tágabb jelentés-kontextusoktól, vagyis attól, hogy milyen szervezeti - intézményi közegben, illetve milyen történelmi - társadalmi - kulturális kontextusban (mint szövegösszefüggésben) kerül sor az értelemadásra. Ebben a sokdimenziós összjátékban születik és alakul e cikk jelentése. Így a szervezet interpretatív megközelítésének most következő bemutatása annyiban nem „objektív", hogy nem egy jelentéshorizontoktól független „,igazság”, hogy is lehetne az? De nem is egy személyes, 
„szubjektív” (értsd: önkényes, elfogult) beszámoló; nem szabad annak lennie! Az interpretatív megközelítés nem relativisztikus, az értelmezés nem szabadon választott. Távolról sem vagyunk felhatalmazva arra, hogy „,bármit értsünk rajta”" Azzal, hogy az értelmezés nem egy lezárt esemény, hanem egy alkotó és le nem záruló folyamat, megnő az értelmezésben résztvevők felelőssége. Felkészülés és ráhangolódás, tudatosság, önreflexió, alázat csak néhány azon magatartásformák közül, melyek alapvetők az értelmezésben, s így a szervezet interpretatív megközelítésében is. Folyamatos feladatunk, hogy az igazságra törjünk, még'ha nem is érhetjük el soha.

\section{A szervezetelmélet episztemikus jellege - szervezetelméleti paradigmák}

Számomra 1995-ben, a belgiumi Leuvenben töltött kutatói ösztöndíjam során következett be a szinte teljes elbizonytalanodás mindabban, amit szervezetekről, vezetésről és valóságról korábban hittem és tanítottam. Néhány sokkoló állítás, melyekkel szembetalálkoztam:

„A szervezet nem létezik, ez egy fogalmi konstrukció ... a valóságot mi együtt konstruáljuk ... a szervezeti valóság egy hatalmi-politikai alkufolyamatban definiálódik."

„Minden csak nyelvileg létezik ... a valóság és az igazság nem ismerhető meg, ezekről pusztán eltérő történeteket - narratívákat - mondhatunk."

"A szervezetek maguk konstruálják meg környezetüket, amihez aztán alkalmazkodnak"

„Nem azok a vezetők, akik helyesen ismerik fel a körülményeket. Ehelyett azok válnak vezetővé, akik a már létező, erőteljes előképük alapján „,megtalálják" - az önbeteljesítő jóslat logikájának megfelelően létrehozzák - saját „rendjüket” az egyébként többértelmű, kaotikus, rendetlen valóságban, s ezzel stabilitást, biztonságot nyújtanak mások számára" (Weick, 1984 alapján).

„A társadalmi jelenségeket nem természettudományos módszerekkel kell vizsgálni; az embereket társ-kutatókként be kell vonni a róluk szóló kutatásba ... legyen a kutató saját világa is a kutatás tárgya."

A rendteremtéshez a fogódzókat nekem a szervezetelméleti paradigmák adták meg. A szervezetelmélet és a szervezetkutatás legutóbbi két évtizedében már nyilvánvalóvá vált, hogy a szervezetek megértése és vizsgálata nagyban függ a mögöttes paradigmától, attól, hogy milyen előfeltevések talaján állva közelítjük a szervezetet (Gioia - Pitre, 1990; Scherer, 2002). Kuhn (1984) paradigmafogalmát tágan értelmezve és a szervezetekre alkalmazva azt olyan általános szemléletként és jellemző gondolkodásmódként foghatjuk fel, amely alapvető hiedelmeket és meggyőződéseket tükröz a szervezeti való- ság lényegéről (ontológia), a szervezeti tudás természetéről (episztemológia), az emberi természetről, valamint e jelenségek tanulmányozhatóságáról (metodológia) (Gioia - Pitre, 1990). Eltérő szervezetelméleti paradigmákban más számít „elmélet”-nek, és különbözik az elméletalkotás célja; látszólag ugyanabban a témakörben más kutatási kérdéseket, más módon vizsgálnak, és jellegében is eltéro válaszokhoz jutnak. „Ugyanaz” a fogalom így egészen mást jelenthet a különböző paradigmákban'. Nem a „Hiszem, ha látom!”, sokkal inkább a „Látom, mert hiszem!” logikája ez. Összefoglalva, a szervezetelméleti paradigma implicit vagy tudatosított módon, de mindenképp, meghatározza számunkra (legyünk épp szervezeti tagok, vezetők, szervezeti tanácsadók vagy szervezetkutatók), hogy:

- Mi a valóság a szervezetben ( $\mathrm{s}$ mi nem az)?

- Mi számít releváns problémának (s mi nem)?

- Mi is a célunk (s mi nem)?

- Milyen is a ,jó”, az „,egészséges”, a „sikeres”, a „megteremtendő” szervezet (s mi nem)?

- Mi számít releváns módszertannak (s mi nem)?

- Hogyan mérjük a siker elérését (s hogyan ne)?

- Mindez kinek is az érdeke (s kié nem)?

A paradigma egyszerre bevett szemléletmód és elfogadott cselekvésminta. Ráadásul mindez kollektiv, azaz nem egyéni észlelési szűrő, hanem egy közösségé, és jellemzően implicit, azaz nem tudatosult e közösség számára. Tehát: „Látjuk, mert hisszük - de nem tudunk erről!".

A szervezetekről való tudás episztemikus jellege (paradigmafüggősége) miatt nem véletlen, hogy sokan felszólítanak a paradigma-tudatos elmélet-építésre és szervezetkutatásra. A mögöttes előfeltevések és meggyőződések tudatosítása - és tudatos felülvizsgálata - a szervezetkutatásban azért fontos, mert

- egyrészt már maga a vizsgálat tárgya, a szervezet, is egy komplex jelenség, melynek elemzése többszempontú közelítést igényel,

- másrészt, ahogy arról szó volt, mert az eltérő előfeltevések alapján a vizsgált jelenség, illetve a kutatási probléma is megváltozik,

- harmadrészt, mert a szervezetek árnyalt és sokoldalú megértését ugyanakkor csak olyan dialógus szolgálhatja, amelyben a mögöttes feltevésekről is szóba állunk.

Ráadásul - $\mathrm{s}$ itt válik mindez húsbavágó gyakorlati kérdéssé -, mert a szervezetelméletek maguk is alakítják azt a szervezeti valóságot, melyet vizsgálnak: az eltérő perspektívák alapján ugyanis eltérő következtetések adódnak a „sikeres” és „kívánatos” szervezetekre vonatkozóan, s e következtetések végül jellemzően szervezetalakítási tanácsokban, vezetési trendekben és menedzsmentdivatokban öltenek testet. Ez a szervezetelméletek 
politikai és morális természetének lényege (Astley - Van de Ven, 1983; Morgan, 1986, 1995; Gioia - Pitre, 1990; Kieser, 1995; Scherer, 2002).

Gibson Burrell és Gareth Morgan (1979) mérföldkőnek tekinthető rendszerezését ( 1 . ábra) és annak jelentőségét a hazai szakirodalomban már taglalták néhányan, ismereteim szerint elsőként Bokor (1994), de magyar nyelven lásd pl. Scherer (2002) kiváló kifejtését is; az alap-paradigmák részletes bemutatásától ezért most eltekintek. De vajon mennyire értjük a modell lényegi jelentését? A következőkben kizárólag az alapdimenziókat értelmezem, számomra egyértelmủ ugyanis, hogy a korábban említett problémák ezek félreértéséből származnak. Mindez egyben az interpretatív szervezetközelítés részletes tárgyalását is előkészíti.

\section{A Burrell és Morgan (1979) által azonosított szociológiai / szervezetelméleti paradigmák} (egyszerüsítve)

\begin{tabular}{|c|c|c|c|}
\hline \multicolumn{4}{|c|}{ Változtatásszociológia } \\
\hline \multirow{2}{*}{$\begin{array}{r}\text { Szubjektív } \\
\text { valóság } \\
\text { (,,cselekvés”) }\end{array}$} & $\begin{array}{c}\text { Radikális } \\
\text { humanizmus }\end{array}$ & $\begin{array}{c}\text { Radikális } \\
\text { strukturalizmus }\end{array}$ & \multirow{2}{*}{$\begin{array}{l}\text { Objektív } \\
\text { valóság } \\
\text { („,struktúra”) }\end{array}$} \\
\hline & $\begin{array}{l}\text { Interpretatív } \\
\text { szociológia }\end{array}$ & $\begin{array}{c}\text { Funkcionalista } \\
\text { Szociológia }\end{array}$ & \\
\hline \multicolumn{4}{|c|}{ A rend szociológiája } \\
\hline
\end{tabular}

A Burrell-Morgan mátrix a társadalmi és szervezeti valóság vizsgálatának négy paradigmáját két dimenzió mentén határolja $\mathrm{el}^{6}$. A paradigma fogalom ,elfogadott minta”, illetve „összefüggő hagyomány” jellegéből következik, hogy egy-egy paradigmához - azaz a modell egy-egy síknegyedébe - sokféle szervezetelmélet, irányzat és megközelítés sorolható, vagy másképp: hogy tudomány- és társadalomelméleti alapfeltevéseiket tekintve egymástól egészen eltérő szervezetelméletek mégis egy csoportba tartoznak. Így például egyaránt funkcionalistának számítanak a klasszikus menedzsmenttanok, Weber bürokráciaelmélete, a human relations irányzat, a klasszikus rendszerelmélet, az erre épülő strukturális kontingenciaelmélet, az intézményi közgazdaságtani elméletek, a szociológiai institucionalizmus vagy a populációs ökológiai közelítés.

A modell vízszintes tengelye a tudományfilozófiai dimenzió, mely a (szervezeti) valóság szubjektív versus objektív természetének elöfeltételezése alapján rendszerezi a szervezetelméleteket. Ez egyben előfeltevést jelent az emberi természetről, pontosabban, az emberi akarat és cselekvés szabadságának mértékéről is.

Az objektivista tudományfilozófiai alapállás a természettudomány valóságértelmezésének mintájára fogja fel a társadalmi valóságot, és a természettudományi kutatás-ideál mintájára közelíti a társadalomtudományi kutatást. Az ide sorolható szervezetelméletek „objektív” szervezeti és környezeti valóságot előfeltételeznek, ennek megfelelően, a szervezetek lényegét számukra a megfigyelő(k) szubjektumától függetlenül létező, s enynyiben „külső”, szervezeti realitás jelenti. A pozitivista ismeretelmélet szerint a társadalmi és szervezeti valóságot az ok-okozati viszonyokként jelentkező általános törvényszerűségek (a „társadalmi struktúrák”) határozzák meg. A feladat ennek megfelelően az, hogy az operacionalizálás során minél relevánsabb változókkal, és a változók közötti (statisztikai) összefüggések leírásával, minél érvényesebb magyarázatot adnjunk a társadalmi és szervezeti valóságot meghatározó általános törvényszerűségekről, univerzális működési mechanizmusokról (ún. „magyarázat”). Az emberi cselekvésmintákat eszerint, egyéni és kollektív szinten egyaránt, elsősorban a cselekvők tudatától függetlenül („objektíve”) létező külsődleges struktúrák, törvényszerüségek határozzák meg; e valóságfelfogást emiatt „deterministának” is nevezik (Astley - Van de Ven, 1983; Blaikie, 1995). Az objektivista alapállás az empirikus szervezet-kutatást tekintve is feltételezi az „objektivitást”, azaz a kutatói értékmentességet, és azt, hogy a kutatás során a vizsgált rendszer érintetlenül hagyható. A kutatói objektivitást a megfelelően alkalmazott tudományos módszertan biztosítja.

Példaként, a strukturális kontingenciaelmélet először definiálja a formális szervezeti struktúra, illetve a külső környezet releváns dimenzióit, majd ezek között általános összefüggéseket tár fel (a szervezeti struktúrát például a környezet változékonyságából és komplexitásából vezeti le; pl. Kieser, 1995). A jellemző tévhittel szemben a szervezeti magatartástudomány $(\mathrm{OB})$ vagy az emberierőforrás-menedzsment (HRM) klasszikus megközelítései is objektivista-funkcionalista alaptermészetűek, amennyiben fő céljuk a vizsgált jelenségek mögötti általános törvényszerűségek feltárása, magyarázata és előrejelzése.

Ezzel szemben, a szubjektivista tudományfilozófiai alapállás szerint a szervezeti valóság nem látható és nem vizsgálható közvetlen módon, hiszen a szervezetek lényegét azok a mögöttes jelentéstartalmak és értelmezések jelentik, melyek a szervezeti szereplők tudatában és interszubjektív folyamataiban, azaz interakcióik és kommunikációjuk révén „léteznek”. A szervezeti valóságot az interakciókban kialakuló jelentések hozzák létre, tartják fenn vagy változtatják meg; a szervezetkutatás is csak a helyi értelmezések, jelentések és interakciók megértésén keresztül lehetséges. Mindez párosul a kutató aktív valóság-konstruáló szerepének feltételezésével, s így lehetetlennek tartja a kutatói objektivitást, semlegességet és értékítélet-mentességet. Ez az alapállás tehát nem az általános jelenségek felé fordul; s nem az álta- 
Objektivista és szubjektivista tudományfilozófia

(saját rendszerezés, Morgan - Smircich (1980) tanulmányát felhasználva)

\begin{tabular}{|c|c|c|}
\hline Szempontok & Objektivista tudományfilozófia & Szubjektivista tudományfilozófia \\
\hline $\begin{array}{l}\text { Ontológia } \\
\text { (lételmélet) } \\
\qquad \text { Mi a valóság? }\end{array}$ & $\begin{array}{l}\text { - A megfigyelő szubjektumától független és konkrétan } \\
\text { létező, ,külső” szervezeti valóság. } \\
\text { - Általános társadalmi-szervezeti törvényszerűségek } \\
\text { („,struktúrák”) érvényesülése. }\end{array}$ & $\begin{array}{l}\text { - Társadalmi / szervezeti valóság: szimbolikus, kul- } \\
\text { turális, nyelvi - rejtett jelentések. } \\
\text { - Szervezeti valóságalakulás: társas konstrukciós folya- } \\
\text { mat - kommunikáció, interakció, befolyásolás, alku } \\
\text { - Helyileg definiálódó valóság. }\end{array}$ \\
\hline $\begin{array}{l}\text { Emberkép } \\
\text { Milyen az emberi } \\
\text { cselekvés természete? }\end{array}$ & $\begin{array}{l}\text { - A magatartást a háttérben általános, az aktuális cse- } \\
\text { lekvőktől független hatóerők, törvényszerűségek } \\
\text { alakítják (,,struktúra”, determinizmus). }\end{array}$ & $\begin{array}{l}\text { - Az emberi tudat, cselekvés és interakció helyileg } \\
\text { konstruálja a (szervezeti) valóságot. } \\
\text { - Közösen létrehozott és elfogadott kollektív valóság } \\
\text { („,cselekvés”, voluntarizmus). }\end{array}$ \\
\hline $\begin{array}{l}\text { Episztemológia } \\
\text { (ismeretelmélet) } \\
\text { Hogyan ragadható } \\
\text { meg a valóság? } \\
\text { Mi a tudás? }\end{array}$ & $\begin{array}{l}\text { - Tudás/cél: az általános törvényszerűségek feltárása és } \\
\text { előrejelzése (magyarázat). } \\
\text { - Étikus megközelítés: általános fogalmak mentén. } \\
\text { magyarázza az egyedit. } \\
\text { - A kutató kívülálló (értékmentesség). } \\
\text { - A szervezetet érintetlenül hagyó kutatás. }\end{array}$ & $\begin{array}{l}\text { - Tudás/cél: a helyi jelentéstartalmak (,Mi mit jelent } \\
\text { itt?”), és a valóságkonstrukciós folyamat (Hogyan jön } \\
\text { ez létre?”) megértése (jelentés-megértés), illetve a } \\
\text { helyi cselekvésmagyarázat (,Mi az oka itt?”). } \\
\text { - Émikus megközelítés: a helyi fogalmak mentén. } \\
\text { igyekszik magyarázni az egyedit (ill. az általánost). } \\
\text { - A kutatás/kutató mindig értéktelített és elfogult. } \\
\text { - A kutatás is alakítja a szervezeti valóságot. }\end{array}$ \\
\hline $\begin{array}{l}\text { Metodológia } \\
\text { (módszertan) } \\
\text { Hogy szerezzünk } \\
\text { ismeretet? }\end{array}$ & $\begin{array}{l}\text { - Pozitivista módszertan: pl. tudományos (kvázi) kísér- } \\
\text { let, többváltozós matematikai-statisztikai elemzés. } \\
\text { - Jellemző módszerek: nagymintás kérdőívelemzés, } \\
\text { kvantitatív interjúzás, dokumentumelemzés. }\end{array}$ & $\begin{array}{l}\text { - Jelentésmegértés: pl. hermeneutikai és fenomenoló- } \\
\text { giai elemzés, kvalitatív esetelemzés. } \\
\text { - Grounded theory. } \\
\text { - Jellemző módszerek: mélyinterjúzás, résztvevő-meg- } \\
\text { figyelés, diskurzus-elemzés, napló módszertan, cogni- } \\
\text { tive mapping stb. }\end{array}$ \\
\hline $\begin{array}{l}\text { A szervezet } \\
\text { metaforái }\end{array}$ & - Pl. gép, rendszer, organizmus. & $\begin{array}{l}\text { - Pl. interpretatív rendszer, kollektív tudat, kultúra, szö- } \\
\text { veg ('text'), dráma, nyelvjáték, szervezeti tudattalan. }\end{array}$ \\
\hline
\end{tabular}

lános - az adott kontextusok feletti - törvényszerűségeket keresi. Vagy, ugyan nem eleve elutasítva ezek létezésének lehetőségét, azért nem ez a szint érdekli, mert a társadalmi-szervezeti valóság lényegének megragadásához túl távolinak tartja ezt az ún. „helikopter-szemléletet". Vagy pedig eleve tagadja létuiket, ugyanúgy társadalmilag létrehozott és fenntartott (fogalmi) konstrukciókként kezelve ezen ,általános törvényszerüségek”-et és „változókat”, mint a társadalmi-szervezeti valóság más „,tényeit”, köztük pl. magát a „,szervezet”-et. Bármelyik legyen is, a szubjektivista alapállás arra kíváncsi, hogy egy adott helyen és időben (konkrét csoportban, szervezetben, közösségben stb.) milyen helyi értelmezések és cselekvésmagyarázatok jönnek létre és maradnak fenn azzal kapcsolatban, ami „,van”; illetve ezek miként konstruálódnak (ún. „megértés”). Az 1. ábrán a „cselekvés” fogalom arra utal, hogy ez annyiban egy „voluntarista" megközelítés, amennyiben az emberi tudatot, cselekvést és interakciót tekinti valóság-definiáló erejűnek. Ugyanakkor, szemben minden degradáló tévhittel, ez távolról sem egy szubjektív idealista felfogás, amely az egyén tudatát tekintené minden létező alapjának, vagy tagadná az egyéntől függetlenül létező valóságot (vö. Bakos,1983). Nincs szó arról, hogy az egyén, önmagában és szabadon, képes lenne ,átdefiniálni” a történelmileg, társadalmilag és szervezetileg - azaz mindenképp kollektív és kulturális módon - létrejövő valóságot. Sőt, amint arról szó lesz: nem is az egyén, hanem a közösség, a „kollektív” számít az értelmezés, a jelentésadás és a valóság-definiálás alapegységének. Emellett, s ezt is kifejtem majd, az aktuális értelmezéseken túl számos rögzült és intézményesült jelentésdefiniáló mechanizmus működik mind a társadalomban (pl. hagyomány, jog, piac, média, hit, oktatás), mind a szervezetben (pl. formális és informális hierarchia, szabályzatok és bevett működésmódok, stratégiák, a szervezeti kultúra más orientáló elemei). De fontos, hogy ezek mindig helyileg és specifikus módon fejtik ki jelentésbefolyásoló hatásukat. Az 1. táblázat a fentieket foglalja össze.

$\mathrm{Az}$ objektivista-pozitivista alapállásból a vizsgált jelenség étikus megközelitése következik. Ez arra utal, hogy a jelenség leírása és operacionalizálása elméleti változókkal történik - a vizsgált társas rendszer szempontjából nézve külsődleges és általános fogalmakkal, mint pl. „feladatmegosztás”, „hatáskörmegosztás” és „koordináció” a formális struktúra esetében, ,hatalmi távolság index" és ,bizonytalanságkerülés index" a nemzeti kultúra esetében. A szubjektivista-interpretatív alapállás ezzel szemben émikus megközelítés: a helyileg vizsgált valóságot minél inkább az adott közösségben használt belső fogalmak, a helyi vagy „laikus” nyelv mentén igyekszik leírni és megérteni. Az émikus-étikus megközelítések részletes bemutatását lásd Primecz Henriett e lapszámbéli tanulmányában. 
Most térjünk rá a Burrell-Morgan mátrix függőleges tengelye által jelölt társadalomelméleti dimenzióra, amely a szervezetelméleteket aszerint kategorizálja, hogy „a rend szociológiáját” vagy a „változtatásszociológiát” képviselik-e. Szokták „társadalmi rend” vs. „radikális változás" dimenziónak is nevezni. A rend szociológiája a társadalmi rend és konszenzus lehetőségének előfeltételezésével él, azaz, hogy a különféle (osztály)érdekek végül is összeegyeztethetőek, s a szervezeti szereplők között megteremthető az összhang (pl. a vállalati célok válhatnak többé-kevésbé „közös céljaink”-ká). A változtatásszociológiai kiindulópont ellenkező alapálású, a szervezeti valóságot alapvetően ellentmondásosnak, feszültségekkel telinek véli. A stabilitás eszerint csak látszólagos, manipuláció vagy elnyomás eredménye, az eredendően ellenérdekelt csoportok közötti küzdelem pedig elvezet(het) a kívánt forradalmi változásokhoz.

A rend szociológiájához sorolt elméletek tehát a fennálló szervezeti és társadalmi valóságot vizsgálják - vagy objektivista, vagy szubjektivista tudományfilozófiai alapállásból. Sokan úgy hiszik, hogy ebbe csak a leíró jellegű, az aktuális status quora vonatkozó („Hogy vannak a dolgok?") kérdésfeltevések férhetnek bele, míg a normatív jellegű, változtatásorientált („Hogy legyenek a dolgok?”; „Hogy kellene lennie a dolgoknak?”) kérdésfeltevések nem. Ez komoly félreértés, mint ahogy az is, ha a változtatási szándékot önmagában véve már változtatásszociológiai alapállásként értelmezzük! Ahhoz, hogy ezt belássuk, fontos értenünk, hogy mire is vonatkozik társadalomelméleti értelemben a „radikális változás" kifejezés. Nos, ez társadalomkritikát jelent: a Burrell és Morgan által a változtatásszociológiához sorolt társadalom- és szervezetelméleti irányzatok az uralkodó társadalmi - gazdasági - politikai berendezkedést bírálják, s azt vagy megreformálni kívánják (pl. a frankfurti iskolán alapuló kritikai elmélet), vagy eleve elutasítják (pl. a marxista elméletek). Legyünk még egyértelmúbbek: nem akármelyik társadalmi berendezkedés, hanem a kapitalizmus, a mai fogyasztói társadalom áll itt a bírálat középpontjában:

(A kritikai elmélet szerint)...A kapitalista társadalom alapvetően irracionális, mivel nem képes kielégíteni a létező igényeket, miközben hamis vágyakat és igényeket teremt" (Blaikie, N., 1993; kiemelés tőlem - G. A.).

Vagy egy másik megfogalmazás Max Horkheimertől, a frankfurti iskola egyik korai és jeles képviselőjétől, az ún. ,immanens kritika” kapcsán:

„... (az immanens kritika) egy szöveg állításai és a tényleges gyakorlat közötti totális ellentét feltárása. Célja bemutatni, hogy a burzsoá társadalom miként szegi meg forradalmi ígéretét, mely az ‘igazságról, egyenlőségről és szabadságról' szól' " (Boje, 1998; kiemelés tőlem - G. A.).
A változtatásszociológiai alapállás az egyenlőtlenség, kizsákmányolás és elidegenedés történelmileg kialakult társadalmi-szervezeti „rendjének” megváltoztatásáért lép fel; objektivistaként az elnyomó osztályviszonyok és gazdasági berendezkedés forradalmi átalakításáért, míg szubjektivistaként az ideológiák uralma ellen, azaz a „,megváltoztathatatlan”-ként felfogott, elfogadott és fenntartott társas valóság megreformálásáért küzdve.

A Burrell-Morgan mátrix alapján az interpretatív szervezetközelítés szubjektivista tudományfilozófiát és a rend szociológiáját képviselő társadalomelméleti alapállást jelent (1.ábra). A következőkben részletesebben is kifejtem ezt.

\section{Interpretatív szervezeti paradigma - interpretatív szervezetelmélet}

Az interpretatív szervezetelméleti megközelítés a társadalomtudományok ún. interpretatív paradigmájának $^{7}$ szervezetelméleti alkalmazását jelenti (Wollnik, 1995). Bár nincs szó homogén irányzatról, a lényegi kiindulópontokat tekintve sokak szerint mégis beszélhetünk egy interpretatív szervezetelméleti iskoláról. A következőkben együtt kezelem a szervezet különféle interpretatív, konstruktivista és konstrukcionista felfogásait is - bár nem tehető közéjük egyenlőségjel, közös intellektuális hagyományt képeznek. Az együttes tárgyalás jogalapjaként sokatmondó, hogy Kieser, az általa szerkesztett Szervezetelméletek c. mú újabb kiadásában minden további nélkül „konstruktivistára” keresztelte át a korábbi „interpretatív" fejezetet (Wollnik, 1995; Kieser, 2002). Bár az azonosságok mellett fontosak a különbségek is, ezek bemutatása túlmutatna jelen tanulmány keretein (hermeneutika és szociálkonstruktivizmus összehasonlításáról lásd Ropolyi (2000), a különféle interpretatív és konstruktivista irányzatok fejlődéstörténetéről pedig Schwandt (1999) kiváló írásait). Viszont fontosnak tartom tisztázni saját alapállásomat: a szervezet interpretatív megközelítése nálam leginkább a hermeneutikai orientációt jelenti - nem véletlen, hogy külön is szólni fogok a „megértés”-ről (Verstehen) mint oly alapvető interpretatív fogalomról.

Amint az 1. ábrából látható, Burrell és Morgan rendszerezése alapján az interpretatív szervezetelmélet a szervezeti valóság szubjektív és konstruált természetét feltételezi, elsődleges célja pedig a megértés, a szervezeti valóság mélyelemzése. Ebből fakad, hogy a fóáramot jelentő funkcionalista szervezetelméletek társadalomelméleti kritikáját ugyan nem fogalmazza meg, tudományelméleti oldalról viszont radikális bírálatukat adja, és hibás ,izmusokkal” vádolja őket:

1. Objektivizmus: az az implicit feltételezés, hogy a szervezeti valóság „létezik”, lényege megragadható, mérhető és tervszerủen alakítható, 
2. Determinizmus: az az implicit feltételezés, hogy a szervezet egyoldalúan függ környezetétől, s ahhoz ily módon alkalmazkodik,

3. Redukcionizmus: az az implicit feltételezés, hogy a szervezetek vizsgálatakor vizsgálati tényezők (változók) és általános oksági összefüggések (függő és független változók) azonosítandók,

4. Funkcionalizmus: az az implicit feltételezés, hogy 1) a „szervezeti alkalmazkodás” kérdésköre kell, hogy a szervezetelméletek lényegi problematikája legyen, mivel 2) a jól alkalmazkodó szervezet társadalmilag is hasznos (ennek ellenkezője fel sem merül); és végül, már ,,izmus-mentesen”,

5. Kutatói értékmentesség: az az implicit feltételezés, hogy 1) a kutató képes lehet „kívül maradni”, azaz a kutatással nem beavatkozni a vizsgált szervezeti rendszerbe, illetve 2) hogy elfogulatlan maradhat, azaz elérhető, hogy a kutatás és a kutató ne képviseljen érdekeket.

Az interpretatív elmélet az objektivizmusra a társas konstrukcióval felel, s a szervezeti valóság lényegét rejtettnek és folyamatosan alakulónak tartja. A determinizmusra adott - voluntaristának nevezhetô - válasz is a valóság konstruált jellegéből fakad, amennyiben a szervezet a maga által konstruált környezettel van kapcsolatban, arra „reagál”. A redukcionizmus bírálatának az a lényege, hogy a szervezetben - ahol minden „változó" jellemzően egyszerre függő és független, s leginkább maga is egy konstrukció -, az alapfeladat nem az általános magyarázat, hanem épp a helyi jelentések és öszszefüggések megértése. A funkcionalizmust a szervezeti valóságkonstrukció vizsgálata váltja fel, s ennek elemeként pl. az „alkalmazkodási retorika” elemzése; míg az értékmentesség feltételezése helyett a kutató aktív valóságkonstruáló szerepét és értéktelítettségét állítja. A 2. táblázat a fentiekhez kapcsolódóan foglalja össze az interpretatív szervezetfelfogást.

\section{Az interpretatív szervezetközelítés lényege és alapfogalmai}

Mindezek után részletesebben is fogalmazzuk meg az interpretatív szervezetelmélet lényegét, értelmezzük a már említett fogalmakat és állításokat. Mit értsünk például azon, hogy az interpretatív felfogás a szervezeti valóság szubjektív és konstruált természetét feltételezi, s hogy elsődleges célja a megértés?

\section{A szervezeti valóság, mint a társas konstrukcióban létrejövő közös jelentésvilág}

A különféle szervezetelméletek és a szervezeti gyakorlat általában előfeltételezik, magától értetődőnek veszik a „szervezet”-et mint kollektív egységet, holott az egyáltalán nem nyilvánvaló. Az interpretatív szervezetelmélet viszont alapkérdéssé teszi és explicite is megválaszolja az „egyének feletti” vagy „egyéneken túli” szint mibenlétét, s így ontológiailag átreflektált hátteret jelent végső soron a szervezetelméletekhez is. A szervezeti valóság eszerint egy társas (társadalmi-közösségi) konstrukció (socially constructed), s a dolgok szervezeti jelentése társas értelmezési folyamatokban alakul ki (socially construed). A fó kérdés pedig az, hogy mi mit jelent a szervezetben és miért, mely szereplők definiálják a szervezet valóságát és milyen folyamatban, illetve milyen közös jelentésminták jönnek létre, maradnak fenn és válnak domináns valóság-alakító erővé a szervezetben.

\section{Interszubjektív és közös szervezeti jelentések}

A szervezeti valóság a szervezeti szereplők cselekedetei és interakciói révén jön létre, alakul és változik. A szervezeti szereplők viszont különféle - előzetesen már létező - értelmezések és jelentéstartalmak alapján vesznek részt e helyzetekben, cselekedeteikben és interakcióikban. Az egyének jelentést adnak például a külvilág eseményeinek, saját maguknak és mások személyének vagy tetteinek, de az egyéni jelentésadás irányul a szervezet múltjára, jelenére és jövőjére csakúgy, mint a különféle tárgyi és szimbolikus alkotásokra. Az egyéni észlelések, értelmezések és cselekedetek az interakciók során viszont befolyásolják egymást: a tettek és azok eredményei (például a létrehozott tárgyak), illetve a különféle szervezeti események szimbolikus jelentést kapnak. A szervezeti valóság lényegét így nem a külső szemlélő számára is látható és megfigyelhető szervezeti események és interakciók, és nem az általánosan érvényesülő szabályszerűségek (struktúrák) jelentik, hanem az interakciókban létrejövo” „interszubjektív” és mögöttes jelentéstartalmak.

$\mathrm{Az}$ interszubjektív jelentésvilág önmagában még nem szükségszerűen kell, hogy „,közös” (együttes, azonos) értelmezéseket takarjon - a szervezetek egyes konstrukcionista, illetve posztmodern felfogásai meg is kérdőjelezik e közös jelentésrendszer létét (Schulz Hatch, 1996; Kvale, 1996; Weisinger - Salipante, n.a.). $\mathrm{Az}$ interpretatív szervezetfelfogás viszont egy adott többnyire szubjektív módon behatárolt - közösség szintjén feltételezi a közös jelentésvilágot, és azt, hogy ezekből (többé-kevésbé) közös szervezeti jelentésvilág, azaz közös kognitív, nyelvi és kulturális háttér alakul ki (pl. Weick, 1979; Smircich, 1983a; Sims - Gioia, 1986; Bougon, 1992; Eden, 1992). De a szervezet így sem egy homogén valóságot jelent, hanem sokféle eltérő valóság - közösség vagy szubkultúra - létezését, s a „közös”nek mondható szervezeti valóság (a „szervezet”) épp ezek interakciójában alakul ki idővel. A közös jelentések egyébként azért fontosak, mert ezek biztosítják a szervezet különböző szereplői számára egymás megértését, koherenciát teremtenek, irányt mutatnak számukra, végső soron lehetővé teszik a kollektív, koordinált cselekvést (Bouwen, 1993; Morgan, 1995). Egy szerve- 
Az interpretatív szervezetfelfogás áttekintése (saját összegzés)

\begin{tabular}{|c|c|}
\hline Interpretatív szervezetfelfogás & Értelmezés \\
\hline $\begin{array}{l}\text { A szervezet lényege: társas konstrukció; mögöttes, } \\
\text { rejtett jelentések. }\end{array}$ & $\begin{array}{l}\text { - A szervezeti valóság: társas (közösségi) konstrukció. } \\
\text { - A szervezetben a dolgok másról szólnak, mint aminek látszanak: a szervezetek } \\
\text { lényege rejtett. } \\
\text { - A tényleges szervezeti valóság a fejekben, érzésekben, identitásokban, } \\
\text { szándékokban, érdekekben, interakciókban „létezik”. } \\
\text { - A szervezet szimbolikus, kulturális, nyelvi és hatalmi jelenség. }\end{array}$ \\
\hline $\begin{array}{l}\text { Helyi, szubjektív és egyedi szervezeti valóság } \\
\text { feltételezése. }\end{array}$ & $\begin{array}{l}\text { - A fő kérdés: a szervezeti szereplők szubjektív értelmezései és interakciói miként } \\
\text { hozzák létre az „ott és akkor” számukra létező „,közös valóság”-ot. } \\
\text { - A szervezet valósága egyedi / azt egyediségében vizsgálja. }\end{array}$ \\
\hline $\begin{array}{l}\text { A környezet-szervezet viszony „,belülről” kiinduló } \\
\text { újraértelmezése. }\end{array}$ & $\begin{array}{l}\text { - A „,külső” környezet is a szervezeten belül kap jelentést, értelmet (belül konst- } \\
\text { ruálódik). } \\
\text { - A szervezet a (részben) maga által konstruált és alakított környezettel van kap- } \\
\text { csolatban, arra „reagál”. } \\
\text { - A külső (társadalmi / politikai / kulturális) környezet hatása közvetett, áttételes: } \\
\text { csak annyiban és oly módon fontos, amennyiben és ahogyan beépül a helyi } \\
\text { szereplők tudatába és nyelvébe. }\end{array}$ \\
\hline $\begin{array}{l}\text { A szervezeti hatalom valóságalakító szerepének } \\
\text { kiemelése. }\end{array}$ & $\begin{array}{l}\text { - A valóságkonstrukció egy hatalmi-befolyásolási folyamat, egy alku (,negotiated } \\
\text { order”). } \\
\text { - Annak a „valósága” érvényesül jobban a „közös” valóság definiálásakor, akinek } \\
\text { nagyobb a befolyásoló ereje. }\end{array}$ \\
\hline $\begin{array}{l}\text { Kutatói fókusz: a résztvevők nézőpontja } \\
\text { Kutatói cél: ,,jelentés-megértés”. }\end{array}$ & $\begin{array}{l}\text { - Kutatói fókusz: a résztvevők nézőpontja, belső és mögöttes jelentésvilága (mi } \\
\text { mit jelent ott, és miért). } \\
\text { - Cél: a kimondottból következtetni a ki nem mondottra, a mögöttesre, a rejtettre } \\
\text { is (,,a szavak mögé nézés”, a „,sorok között olvasás”). } \\
\text { - A kutató is értelmez és befolyásol - a megértés egyben mindig önmegértés. }\end{array}$ \\
\hline
\end{tabular}

zetben általában közös értelmezési sémák és jelentéstartalmak ${ }^{8}$ alakulnak ki például a szervezeti teljesítményre vonatkozóan (Wollnik, 1995), de a szervezet lényegére és identitására, határaira és környezetére vonatkozóan is (Schein, 1992). Az „értelmezés”, ,jelentés” kifejezéseket azonban tágan kell, hogy felfogjuk: gondolatok, érzelmek, észlelések, érdekek, motivációk és tettek nem választhatók el - mind jelentést hordoz, jelentésre épül, egyben jelentést formál.

A közössé váló jelentések egyúttal a közösségi-szervezeti identitás kialakulását - magát a közösséggé-szervezetté válást - is fémjelzik, s párhuzamosan létrejön a közösségi-szervezeti cselekvés lehetősége. Egy szervezet jelentésvilága (vagy kultúrája) pedig kölcsönös, rekurzív viszonyban van e szervezeti cselekvésekkel és interakciókkal: a már „létező” jelentések hátteret jelentenek az aktuális cselekedethez és interakciókhoz, de beágyazódva meg is jelennek azokban, mint ahogy fennmaradásuk és változásuk is e szervezeti cselekvésekben és interakciókban történik meg. A közös cselekvés eredményeként emellett olyan tárgyi alkotások jönnek létre (pl. termékek, technológiák, a fizikai környezet elemei), amelyekhez szintén többé-kevésbé közös jelentéstartalmak kapcsolódnak (Gagliardi, 1990). E tárgyiasult jellemzőkbe egyrészt különféle közös jelentéstartalmak ,ágyazódnak be”, másrészt maguk is kulturális „,̈̈zeneteket” közvetítenek a velük kapcsolatba lépő szervezeti szereplők számára (Yanow, 2000; Gherardi - Nicolini, 2000).

\section{Mögöttes szervezeti jelentések}

Az interpretatív megközelítés kiindulópontja szerint a szervezetben a dolgok másról szólnak, mint aminek látszanak: a szervezetek lényege rejtett; a szervezet egy szimbolikus, kulturális, nyelvi és hatalmi jelenség. Nem véletlen, hogy az interpretatív kutató a szándékosan eltitkolt hatalmi-politikai motívumokat és/vagy a mélyebb, nem tudatos - szimbolikus, kulturális vagy tudattalan tényezőket kutatja. Ebből egyébként az is következik, hogy az interpretatív szervezetelmélet sokkal inkább a szervezeten „belülre” fókuszál, mintsem a szervezet „külső környezetére” (bár tegyük hozzá, ez a megkülönböztetés is egy konstrukció).

Példaként nézzük a „,szervezeti struktúrát”. Funkcionalista értelemben ezt olyan közismert és általános struktúradimenziókkal ragadhatjuk meg, mint „munkamegosztás”, „hatáskörmegosztás”, „koordináció”, ,,szabályozottság”, ,szélességi és mélységi tagoltság”, ,konfiguráció" (Dobák et all., 1996), amelyet a szervezeti és működési szabályzatok, illetve munkaköri leírások rögzítenek. De vajon e dimenziók révén mennyire jutunk közel az adott szervezeti struktúra aktuális jelentéséhez? Természetesen nincs két egyforma SZMSZ, így - az ismert és általánosítható változók mentén - a konkrét SZMSZ egyedileg igyekszik leírni az adott szervezet viszonyait.

S mégis: interpretatív szempontból e struktúradimenziók (e változók), bármennyire testre szabottan alkal- 
mazzuk is őket, mivel „kívülről” közelítik az egyedit, alapjában véve háttérbe szorítják és kiiktatják az érintettek által ténylegesen „megélt struktúrát”, s a kapcsolódó mélyebb jelentéseket. Ha viszont „belülről”, az adott szervezet adott szereplőinek szemszögéből fogjuk fel a „struktúrát”, az sokkal inkább gondolatok, benyomások, érzések és viszonyok alakjában jelenik meg. Interpretatív alapokon a szervezeti struktúra tehát például a következ” módokon „létezik” (de vigyázzunk: ez ismét egy fogalmi elhatárolás, s nem egymástól független, „diszkrét” dimenziók felsorolása): 1) fejekben és tudatban - pl. explicit, illetve implicit gondolatokban, elvárásokban; 2) tudatalattiban - pl. képekben, fantáziákban, intuíciókban, álmokban; 3) szívekben és érzésekben pl. vágyakban, félelmekben, szorongásokban, sikerélményekben, attitüdökben, motivációkban; 4) tettekben, azaz a mindennapi döntésekben és cselekedetekben, 5) interakciókban - például kommunikációban, feladatvégzési folyamatokban és viszonyokban; 6) a kialakult nyelvhasználatban és nyelvben; 7) tárgyakban és berendezésekben; 8) szabályzatokban, elóírásokban, rendszerekben és folyamatokban; ez utóbbiak felfoghatók a szervezeti struktúra „hivatalos verziójaként” is. Ne felejtsük el azt sem, hogy „szervezeti valóság” esetén nem egyéni és eseti értelmezésekről, hanem kollektív jelentésmintákról van szó.

A szervezeti valóság rejtőzködő, de formális elemekben - pl. a konfigurációban - megmutatkozó természetét jól érzékelteti a SCOS (Standing Conference on Organizational Symbolism) szervezet 2. ábrán látható logoja (e szimbólum mélyelemzését Sievers (1990) végzi el).

\section{Helyi valóság, lokális tudás}

Bár a történelmileg és társadalmilag kialakult és fennmaradó jelentésminták is lényegesek a szervezeti valóság konstruálásában, az interpretatív szervezetelmélet

A SCOS Sárkány

(a copyright tulajdonos engedélyével) elsősorban az aktuálisan és helyileg létrejövő (,itt és most") szervezeti valóságot ragadja meg. Minden szervezet valóságát egyedinek tartja, és azt egyediségében vizsgálja; ennek részeként, aktuális és helyi megjelenési formájukban veszi figyelembe a tágabb történelmi-társadalmi hatóerőket is. Hiszen minden - a külső hatások csakúgy, mint a szervezeti események vagy a tárgyi és szimbolikus alkotások - mindig csak egy adott helyi „szövegösszefüggésben”, az adott közösség kontextusában kapják meg konkrét jelentéstartalmukat. Tehát minden valóság „, helyi valóság” : az a közös értelmezésés jelentésvilág, ami az adott közösség számára értelmet ad az eseményeknek, s eligazít a helyes gondolkodást és cselekvést illetően. Ez egyben ,lokális tudás” is, - kompetencia, amellyel csak az rendelkezik, aki tagja ennek a közösségnek, de legalábbis érti és átérzi a közösség jelentésvilágát meghatározó legmélyebb előfeltevéseket (Bouwen - Steyaert, 1995). Egy teljes szervezet „valósága” pedig a különböző egységek és csoportok „helyi valóságainak" összességét és egymásra-hatását jelenti (a szervezeti kultúra irodalomban mindez „domináns kultúra” és a „szubkultúrák” viszonyaként jelenik meg, pl. Schein, 1992). A szervezet emellett egy összetett és „,többszintü" valóság is, amelyben az egyéni, csoportos és szervezeti értelmezések kölcsönösen feltételezik és létrehozzák egymást (Wollnik, 1995).

Egy érdekes helyi konstrukcióként lássuk például a „vödrözés” jelenségét. Ez a speciális fogalom egy multinacionális élelmiszeripari nagyvállalat hazai termelőüzemében alakult ki, ahol a magas szintủ automatizálás egy ponton mégis komolyan sérült: a feldolgozási folyamat - azaz a futószalag - legelején. Ott, ahol az oda beosztott dolgozóknak így napi nyolc órában az volt a feladatuk, hogy egy hatalmas tartályból, sámlira állva és egész nap lefelé hajlongva, vödörrel merjék ki a zöldséget, és egyenletesen terítsék azt el a futószalagon. A kutatói értelmezés óvatosságával ugyan, de megállapítható, hogy a „vödrözés” lokálisan nem csupán a munkaeszközt (a vödröt), a tevékenységet (a vödrözést, azaz a kiemelést, a szétterítést) és a munkatechnológiát (a vödrözés módját) írta le, hanem - a helyi zsargont mélyebben értelmezve, rejtett szinteken - kifejezte a dolgozók alárendeltségét és mindennapi kiszolgáltatottságát is. Mindez egyben „megalkotta” az alanyt, a „vödrözőt”, és a „,ödrözői létet” mint identitást is. A ,vödrözés” mögöttes jelentése tehát sokrétegű, kollektív és tartós volt, és csak helyileg létezett.

E ponton tanulságos összevetnünk az interpretatív és a szociológiai institucionalista szervezetelméletet, hiszen mindkettő a szervezeti valóság konstruált természetét feltételezi, de az utóbbi mégis inkább objektivista alapállásúnak minősüll. Institucionalista megközelítésben ugyanis a „kontextus” nem a helyi, hanem a tágabb társadalmi-intézményi környezetet jelöli, mely általános ér- 
vényű, és az adott szervezet számára adottságként jelentkezik; az institucionalista elmélet ennek megfelelően a szervezet társadalmi-intézményi beágyazottságát vizsgálja (Granovetter, 1990; Walgenbach, 1996). Ezzel szemben „az interpretatív megközelítés számára a szituáció vagy a kontextus azokat a jelentésösszefüggéseket jeleníti meg, amelyek a cselekvő számára relevánsak egy adott idöpontban és orientációs helyzetben" (Wollnik Kieser, 1995: 370.; kiemelés tőlem - G.A.).

A helyi jelentésvalóság előtérbe kerülésével az objektivista tudományfilozófiai alapállás redukcionizmusa azáltal kerül feloldásra, hogy minden szervezeti jelenség helyileg kap értelmet, vagyis nincsenek általános jelenségek; mint ahogy nincsenek általánosan érvényes öszszefüggések sem. Sőt, maguk a „szervezeti jelenségek” is konstruáltak: a megfigyelő a saját jelentésvilága alapján maga nevezi meg ezeket, s csak e megnevezések mentén tapasztalhatja meg a dolgokat. Mivel e mechanizmus alól a kutató sem kivétel, az értékmentes kutatás is csak illúzió.

\section{A nyelv valóságteremtő ereje}

A szervezeti valóság létrehozása, fenntartása és megváltozása szempontjából rendkívül lényeges a nyelv. A nyelv - interpretatív értelmezése alapján - nem pusztán egy eszköz a külső természeti vagy társadalmi valóság egyes elemeinek megnevezésére, sokkal több annál: egy adott szervezetre vagy közösségre jellemző nyelv megjeleníti mindazokat a történelmileg kialakult előfeltevéseket és mögöttes valóságértelmezéseket, amelyek az adott szervezet/közösség lényegét jelentik. Amire van szó a szervezetben, az létezik, s igaz ennek ellenkezője is. A kategorizálások valóságteremtő erejűek - vegyük csak a szervezetbe bevezetett kompetenciaszintek vagy fizetési kategóriák hatását a szervezetre. De egyes felfogások szerint (Winch, 1958) a közös valóság kialakulása, fennmaradása és változása eleve csak kommunikáció révén lehetséges. A közös nyelv kialakulása pedig a közösség létrejötteként, egy közös valóság és identitás létrejöveteleként értelmezhető. A közösség és szervezet számára az általa használt nyelv azonban nemcsak teremtőerő, de korlát is: észlelni, értelmezni és jelentést adni csak meglévő nyelvi kategóriáink (s meglévő értelmezéseink, előfeltevéseink, valóság-definícióink) keretein belül vagyunk képesek, nyelvi-szemléleti-kulturális korlátainkat nem tudjuk ,átugorni” (Watzlawick Weakland - Fisch, 1974; Weick - Westley, 1996) ${ }^{10}$.

A hermeneutikai alapállásnak megfelelően fontos leszögeznünk, hogy az interpretatív megközelítés nem relativista (Grondin, 2002), így a szervezeti nyelv értelmezése sem egyéni mérlegeléstől függ. Ellenkezőleg: ha elég ,jól” értjük, a szervezeti nyelv révén közelebb kell jussunk a szervezet „leglényeg”-ének megértéséhez, ahhoz, amit tudományosan ,a szervezeti kultúra legmé- lyebb közös alapfeltevései"-nek nevezhetünk, de amit a „hely szellemének” vagy a ,szervezet lelkének” is mondhatnánk.

\section{A dialógus jelentősége}

Láthattuk: az interszubjektív jelentések kialakulásában fontos szerep jut a kommunikációnak. Nehézséget jelent viszont a közös értelmezés szempontjából, hogy minden közösség csak a saját története és kultúrája, mint „értelmezési keret” lehetőségein belül képes jelentést adni a valóságnak. Egy saját múlttal rendelkező társas rendszerben (csoportban, szervezetben) az idők során ugyan kialakulnak az adott közösségre jellemző helyi értelmezések, de kérdés, hogy az egymástól különböző szubkultúrák mennyire érthetik meg egymást. ${ }^{11}$

Az interakciók koordinálását egyrészt a konszenzusos jelentéssel bíró, az idők során tudattalanná és meg nem kérdőjelezett jelentéstartalmúvá váló szimbólumok biztosítják (lásd a következő pontban). Az interpretatív hermeneutikai megközelítés azonban túlmegy ezen, és az eltérő jelentésvilágok, kultúrák közötti megértés szempontjából a dialógus fontosságát hangsúlyozza (Gadamer megközelítéséről lásd: Blaikie, 1995). A dialógus fogalom arra vonatkozik, hogy egy, a miénktől eltérő jelentésvalóság megértése csak az adott jelentésvalóság mély, történelmi-kulturális előfeltevés-rendszerének feltárásán és elsajátításán keresztül lehetséges. A cél az, hogy az eltérő előfeltevés-rendszerekből - kommunikáció révén - kialakítsunk egy közös ,,jelentés-horizontot”. Ez azonban nem egyirányú folyamat, hiszen az eltérő kontextus megértése csak úgy lehetséges, ha minden érintett fél felülvizsgálja és módosítja előzetes feltevéseit:

„Egy más jelentés-horizonttal való találkozás ráébresztheti az értelmezőt saját mélyen fekvő feltevéseire, elő́téleteire vagy jelentés-horizontjára, amelyeknek eddig esetleg nem volt tudatában; a tudattalan meggyőződések kritikai tudatosítás tárgyává válnak, és lehetővé válik a valódi megértés" (Blaikie, 1995: 64.).

A dialógus a nyelv alapjain és a nyelv segítségével lehetséges. Más kérdés, hogy - az organikusan kialakuló közös jelentéseken túl - a szervezetekben valódi szándék és tudatos erőfeszítés híján ritkán jön létre valódi dialógus-helyzet, s így egymás szempontjainak mélyebb megértése is sokszor elmarad.

\section{Autonómia: valóság-létrehozás, intézményesülés, tudatosítás}

A szubjektivizmusnak megfelelően az interpretatív felfogás „,voluntarista” megközelítés, ami az emberi tudatot tekinti valóság-definiáló erejűnek: a szervezeti szereplők (csoportok és egyének) eszerint szándékaik, értelmezéseik, tetteik, nyelvhasználatuk és interakcióik 
révén folyamatosan maguk hozzák létre a szervezeti valóságot; ebben az értelemben autonómnak mondhatók. De ez az autonómia nem korlátok nélküli, és nem elsősorban az egyén sajátja. Mint mondtuk, nincs szó arról, hogy az egyén vagy akár a közösség, önmagában és szabadon, képes lenne ,átdefiniálni” a történelmileg, társadalmilag és szervezetileg létrehozott közös jelentésvalóságot. Az autonómiát korlátozó tényezők paradox módon ugyanazok, amelyek az egyén és a kollektíva számára megkönnyítik az interakciót és a cselekvést. A mindennapi kommunikáció és interakció ugyanis nehezen lenne elképzelhető akkor, ha állandóan újra meg újra kellene értelmezni a valóságot, ha mindig meg kellene egyezni egyes szavak vagy más szimbólumok jelentéséről. A társadalmi valóság legtöbb eleme azonban ezt nem is igényli, hiszen azok idővel már a tudatosság hatókörén kívülre kerültek, „külsődlegessé”, ,adottá”, a valóság „elfogadott” és „megkérdőjelezhetetlen” részévé váltak a szereplők gondolkodásában (Berger - Luckman, 1998). Fontos azonban, hogy ezek mindig helyileg, aktuálisan és specifikus módon fejtik ki jelentésbefolyásoló hatásukat.

Ez a beágyazódás és objektiváció a szervezetekben is lejátszódik. A korábbi értelmezések rögzítésében és fenntartásában például fontosak a rögzült interakciós minták és probléma-megoldási módok, a jellemző magatartási válaszok és létrejött társas-hatalmi viszonyok, vagy a nyelv. De a tárgyiasult elemek - szabályzatok, szervezeti struktúrák, technológiák és eljárásmódok - is a helyileg elfogadott valóság-értelmezéseket, mint tudást intézményesítik. Ezek a valóság-elemek később már nehezen tudatosíthatók, s így megkérdőjelezésük vagy megváltoztatásuk is nehéz. Erre jellemzően csak akkor kerül sor, ha a korábbi értelmezések és jelentések valami miatt „nem működnek” (ha például elakad a kommunikáció vagy nem jön létre közös platform a cselekvéshez), illetve, ha az új helyzetek (pl. „környezeti” események) szükségessé teszik az (újra-)értelmezést.

De ismételten: az interpretatív szervezetközelítés szerint a dolgok jelentése nem kívülről adott, hanem helyileg konstruálódik, s ez már önmagában is az autonómia bizonyos szintjére utal; ráadásul az ,,adottság”nak vélt dolgok tudatosításával van mód az autonómia további kiterjesztésére.

\section{A szervezeti valóság formálása: alku, befolyásolás, hatalom}

Ha az interpretatív szervezetfelfogást komolyan vesszük, nem túlzás azt állítani, hogy akik kapcsolatba kerülnek a szervezettel, egyben részt is vesznek a szervezeti valóság alakításában, a közös szervezeti jelentésekről szóló diskurzusban. A szervezeti valóság alakítása leginkább egy állandó „,megegyezési folyamat”-ként vagy ,alku”-ként képzelhető el, amelyben a különféle szervezeti szereplők igyekeznek saját értelmezéseik és érdekeik mentén alakítani a közös jelentést. Az ,alku” ('negotiated order', in: Bouwen, 1993) értelmezhető a teljes szervezet valóságára csakúgy, mint a szervezet egyes rész-valóságaira (szubkultúráira, közösségeire) is. Az első esetben az a tét, hogy mi válik a szervezet egésze számára a cselekvést meghatározó domináns logikává, a második a helyi (adott csoportbeli, közösségbeli) jelentések meghatározásáról szól. Mindkét esetben igaz, hogy a „,belső” szereplők saját értelmezései mellett „,külső” valóságértelmezések is bekapcsolódnak e megegyezési folyamatba (pl. más szervezetek valóságdefiníciói, különféle intézményi logikák, társadalmi diskurzusok és ideológiák).

Amint erről szó volt, az interpretatív megközelítés szerint a különféle értelmezésekből - interakció, kommunikáció révén - ki tud alakulni egy közös megértés és jelentésvilág; ez azonban nem szükségszerű. Elképzelheto, hogy egyes szereplők pusztán „félreteszik” a célokban és értelmezésekben fennálló ellentéteiket, és a közös cselekvés érdekében a közös elemekre koncentrálnak. Máskor egyes szereplők alárendelik saját értelmezéseiket másokénak. A fenti esetekben a közös cselekvés ellenére az értelmezésekben meglévő korábbi különbségek hosszabb távon is fennmaradhatnak (Putnam alapján: Risberg, 1999). Ha viszont a felek között - a korábbi értelemben vett - dialógus létre tud jönni, a közös cselekvés hátterében az eltérő perspektívák is egy közös jelentés-horizonttá „olvadnak össze”.

A közös jelentésvilágról szóló szervezeti diskurzusba ugyanakkor nem minden résztvevő képes egyforma érdekérvényesítő erővel bekapcsolódni: a hatalommal rendelkezők másoknál hatásosabban képesek befolyásolni mind a valóságalkotási folyamatot, mind a kialakuló jelentéstartalmakat. Nem véletlen, hogy sokan a legfőbb vezetői feladatnak és lehetőségnek tartják a közös szervezeti jelentésvilág tudatos formálását (Smircich - Morgan, 1982; Smircich, 1983b; Weick, 1984), vagy a szimbolikus eszközök átgondolt használatát (Morgan, 1995). A vezetési tevékenység ebben az értelemben tehát nem más, mint „értelmezésmenedzsment” (management of meaning): mások értelmezésrendszerének befolyásolása révén a közös szervezeti jelentésvilág tudatos formálása.

Természetesen a „szervezeti hatalom” sem objektív jelenség, hanem maga is társas konstrukció. Ez egy paradox viszonyt teremt: akinek nagyobb a konstruált hatalma, az erőteljesebben befolyásolhatja a szervezeti valóság definiálását; és fordítva, akinek a valóság-definíciói erőteljesebben érvényesülnek a közös szervezeti valóság alakításakor, annak nagyobb lesz hatalma (Gelei, 1996). Weick (1984) szerint a szervezetben éppen azok választódnak ki vezetőnek és kapnak hatalmat, akik a szervezeti rendre vonatkozóan határozott elözetes koncepciókkal rendelkeznek, és képesek is érvényre juttatni ezeket a valóságértelmezéseket. Mások kisebb sze- 
repet tulajdonítanak a vezetésnek. Orton (2000) például az alsóbb hierarchiaszintek valóságkonstruáló erejét hangsúlyozza, amennyiben a vezetés számára sokszor az alsóbb szintek ,állítják elő” az egyáltalán szóba jöhető értelmezéseket vagy döntési alternatívákat. Brown és Duguid (1983) emellett kiemeli, hogy a felülről jövő (vezetői) akaratot mindig csak a helyi gyakorlat-közösség (community of practice) lokális jelentésvilágának megfelelően értelmezik. S ne feledjük el, hogy maga a vezetői valóságmagyarázat is beágyazódik egy szervezeti-kulturális jelentésrendszerbe (Schein, 1992), illetve egy tágabb, társadalmi-intézményi jelentéshálóba (Engeström, 2000).

\section{Szervezet-környezet viszony, szervezeti változás}

A környezeti alkalmazkodás elsődlegessége (determinizmus) helyett az interpretatív szervezetfelfogásból az következik, hogy - bármennyire is meglepő - bizonyos fokig a „külső" környezet is a szervezeten belül konstruált: 1) a szervezeten belül kap jelentést, 2) a szervezet a maga által létrehozott - általa értelmezett és részben általa alakított - környezetre „reagál”. A külső (társadalmi-politikai-kulturális) környezet hatása így csak közvetett, áttételes: a szervezetijelentés-konstrukciós mechanizmusokon átszűrve fejti ki hatását, és csak annyiban és oly módon fontos, amennyiben és ahogyan beépül a helyi szereplők tudatába és nyelvezetébe.

Tulajdonképpen már a „stratégiai választás” Childféle (1972) koncepciója is a vezetés (a domináns koalíció) valóságalakító szerepét hangsúlyozza, de nála a környezet a szervezettől függetlenül létezo „objektív” valóság. Weick (1979) nehezen lefordítható „enactment” fogalma viszont már arra utal, hogy a környezet nem függetleníthető a szervezettől. A szervezetek (vezetői) nem közvetlenül a környezet eseményeit észlelik, hanem előzetesen létező értelmezéseken és magyarázatmintákon keresztül alkotnak képet a környezetről, s a korábbi valóságértelmezések erőteljesen befolyásolják a környezet aktuális definícióit (Morgan, 1995). Így a helyi nyelvi-kulturális kategóriák, az elözetes szervezetés környezetértelmezések erőteljesen befolyásolják a szervezet-környezet interakció jellegét, eredményességét és következményeit is. Interpretatív alapokon újrafogalmazható az „elegendően szükséges változatosság” (requisite variety) rendszerelméleti elve is (magyarul pl: Kindler, 1989): egy szervezet akkor képes megújulni és adaptív maradni, ha sok különböző valóságértelmezés és magyarázatminta létezhet egymás mellett, $\mathrm{s}$ ha a megszokottól eltérő valóságdefiníciók létrehozásával is kísérletezik a szervezet (Weick, 1979, illetve a „többszólamúságról” Bouwen - Steyaert, 1995; Weick - Westley, 1996). A szintén interpretatív alapokon álló „puha rendszerelmélet" (Checkland, 1990) pedig már teljesen a szervezet hatáskörébe utalja a szervezet-környezet határok definiálását, s így a „környezet” meghatározását.

Interpretatív megközelítésben a szervezeti változások kiváltó oka sem önmagában a külső környezet, a változás legalább annyira a szervezeten „belülről” fakad. Eredhet például a megváltozott szervezeti öndefinícióból, a belső interakciós minták átalakulása révén kialakuló újfajta szervezeti jelentésekből, korábban nem létező értelmezések és magyarázatminták szervezeti megjelenéséből, vagy a belső hatalmi viszonyok - s így a domináns valóságdefiníciók - megváltozásából (Gelei, 1996). Más kérdés, hogy az interpretatív elmélet mindezt nem a szervezeti adaptáció (funkcionalista) szempontjából tartja érdekesnek, és nem is a szervezeti alkalmazkodás sikerességét vizsgálja, hanem a szervezeti valóságkonstrukciót, s ennek elemeként például az „alkalmazkodási retorikát” (Honnan ered? Kinek érdeke fenntartani? Mely szereplők miként élik meg? stb.)

E ponton ismét vessük össze az interpretatív és az institucionalista megközelítést! Utóbbi, bár a szervezeti valóság társas konstruáltságát előfeltételezi, létező és alapvető szerepet tulajdonít a külső környezetnek: az intézményesült és/vagy a társadalmi intézményektől „,készen kapott" jelentésminták szerepét hangsúlyozza a szervezeti valóság létrehozásában. Nem véletlen, hogy itt inkább a szervezeti valóság társadalmi felépitettségéről beszélünk, míg az interpretatív elméletben a szervezeti valóság társas- közösségi konstrukciójáról, ezzel is kiemelve a szervezeti szereplők aktív valóságalakító szerepét.

\section{Egy kitüntetett fogalom: \\ a megértés (Verstehen) jelentése és jelentősége}

A következőkben a megértést (Verstehen) nem mint módszertani kérdést, hanem mint a társas valóság - s így a szervezeti valóság - alapkérdését, ontológiáját tárgyalom. Így most más minőségben és tágabban jelenik meg, mint a köznapi értelemben vett fogalom, illetve az olyan rokon kifejezések, mint interpretáció, értelmezés, jelentésadás. Miért fontos ez a soron következő, mégoly vázlatos fejtegetés? Azért, mert annyi kiderülhet belőle: az interpretatív megközelítés sokkal inkább egy filozófiailag vezérelt, de a megélt tapasztalatban megtestesülő hozzáállás a valósághoz (s a léthez), mintsem valamely specifikus eszközrendszer vagy módszertan elsajátítása és alkalmazása. E hozzáállásra például a következő hívószavakkal utalhatunk: érzékenység, ízlés, beleérzés, ítélőerő, életbölcsesség, sőt: hagyományértés, morális érzék, hitelesség, erkölcsileg helyes cselekedet, s végső soron: az igazság szellemében való eljárás. A megértés helyessége nem egy szubjektív (értsd: önkényesen választott) mércétől függ, azaz nincs teljesen ránk bízva, de nem is mérhető eleve adott, objektív kritériumok 
mentén. Nem lezárt, nem egy elérhető véges értelem (nem egy végső igazság), s így mégiscsak erőteljesen függ az értelmezőtől, megértésre-törekvésének fegyelmezettségétől és minőségétől.

A megértés a fenomenológia és - leginkább - a (filozófiai) hermeneutika alapfogalma és alapproblematikája (Gadamer, 2003; Blaikie, 1995; Grondin, 2002; Schwandt, 1999). A hermeneutika végső soron a megértés filozófiája és művészete (Grondin, i.m.). Bár hamar eljut a filozófia alapkérdéseiig, kiindulópontja a következő: „Hogyan érthetjük meg egy szöveg értelmét, jelentését?" A probléma abból fakad, hogy minden egyes szövegben (benne, mögötte, általa) ott van maga a szerző vagy a beszélő is. Lehet, hogy ő ugyan igyekezett szándékát és mondandóját (a közölni kívánt értelmet) minél jobban kifejezni, talán teljesen „beleadva magát”, de ez soha nem sikerülhet tökéletesen. Ugyanez a helyzet a beszélgetésnél is: a beszélő soha nem tudja kifogástalanul kifejezni magát, mert el kellene mesélnie a mondandó teljes hátterét, el kellene mesélnie „önmagát”: „....az általunk használt szavak, ahogyan azok éppen eszünkbe ötlenek, nem képesek kimeríteni mindazt, ami a $<<$ lelkünket nyomja $>>$, azaz a beszélgetést, mely mi magunk vagyunk." (Grondin, i.m.: 168.)

A hermeneutika egy szöveg megírását, egy szóbeli közlést (sőt, általában véve minden alkotást és minden cselekedetet is) mint az eredeti szándéknak legmegfelelőbb nyelv és kifejezésmód keresését fogja fel:

„... keressük a nyelvet, hogy kimondhassuk, ami a szívünkön fekszik" (Grondin, i.m.: 169.).

Ez önértelmezést, ön-megértést is jelent. Ha pedig mások szavait (és tetteit, szimbólumait) értelmezzük, nem elsősorban a szavak szó szerinti jelentésére vagyunk kíváncsiak, hanem a szöveg (tett, kultúra) mint egész jelentésére, a teljes eredeti mondandóra. A megértés során így az olvasott vagy hallott szavak segítségével el kell jussunk magához a szerzői szándékhoz és értelemhez, az elhangzó szó és nyelv mögötti, de ki nem mondott és el nem mondható, „belső szóhoz”, a beszélő „lelkéhez” (Grondin, i.m.). A megértés révén tehát az a célunk, hogy a teljes jelentést, s így a mögöttes jelentésvilágot is képesek legyünk felfogni. Ez elsősorban nem pszichológiai kérdés, hiszen a beszélő nem pusztán önmagát (saját pszichikumát) fejezi ki, mikor ír, beszél, vagy cselekszik, hanem mindazt a tágabb tradíciót vagy kultúrát is, aminek része, amelyben áll, s melytől nem tud függetlenedni. De ugyanez igaz az értelmezőre is: a megértésben egyrészt saját élettörténetével, önmagát képviselve vesz részt, másrészt képviseli saját tradícióját és történelmi korát, ennek talaján áll, mégha nincs is tudatában. A megértés együttjátszást, részesedést jelent: „....részesedést egy értelemben, egy tradícióban, végső soron egy beszélgetésben" (Grondin, i.m.: 167.).
Az ért meg helyesen, aki saját személyes háttere és tágabb hagyományai (beágyazottságai) talaján állva igyekszik belemerítkezni abba a „másik” jelentésvilágba, amely az értelmezni kívánt szó, tett vagy szimbólum mögöttes jelentés-horizontját adja:

„A megértés vagy - ami itt ugyanaz - alkalmazás nem annyira valamiféle önhatalmú szubjektivitás aktusa, mint inkább egy <<hagyománytörténésbe való belekerülés, melyben szüntelenül közvetítés van a múlt és a jelen között $>$. Megérteni egy szöveget a múltból annyit jelent, mint lefordítani azt saját szituációnkra, korunk kérdéseihez szóló választ hallani ki belőle.” (Grondin, 2002:164., aki Gadamert idézi)

Tegyük hozzá: az értelmező annyiban is aktív alkotó a megértés során, amennyiben a megértés mindig „valamilyen szempontból” történő megértés:

... Akkor értünk meg valamit, ha azt úgy alkalmaztuk magunkra, hogy közben valamilyen választ fedeztünk fel benne a mi kérdéseinkre... Minden megértés, különösen mint önmegértés: motivált, azaz kérdések sarkallják, melyek a megértés pályáit már előre meghatározzák. Az, hogy egy szöveg megszólal, csak a ma hozzá intézett kérdéseinknek köszönhető.” (Grondin, 2002: 165.)

A megértés szembetalálkozás - a szerzővel, az ő korával, önmagunkkal és saját életvilágunkkal. A megértés emellett függ a választott alapállástól is: amikor a megnyilvánuló szavak és tettek háttérében mögöttes jelentéseket keresünk, megtehetjük ezt a kétkedés, bizalmatlanság, gyanú és leleplezési szándék alapállásával, a háttérben mögöttes (tudatos vagy tudattalan) hatalomakarást sejtve (a „gyanú hermeneutikája”). De lehetséges a „bizalom hermeneutikája” is, amikor mint alapállást, ehelyett a (már nem naiv) bizalmat választjuk - a másik elfogadását, az általa szándékolt jelentésben való részesülést (a bizalom hermeneutikája) (Grondin, 2002 alapján, leegyszerűsítve).

Végül, röviden, a hermeneutikai kör fogalmáról:

„A szöveg összefüggéséhez hasonlóan, az élet struktúraösszefüggését is az egész és a részek viszonya határozza meg. Minden rész kifejez valamit az élet egészéből, tehát jelentősége van az egész szempontjából, mint ahogy a rész jelentését az egész határozza meg" (Gademer, i.m.: 257.).

A hermeneutikai kör eredendően tehát rész és egész viszonyáról szól a szövegértésben: az adott szó jelentése csak a teljes szöveg jelentésének tükrében érthető pontosan, miközben a teljes szöveg, mely az egyes szavakból épül fel, csak az egyes szavak révén közvetítheti a jelentést; - ez egy állandó, oda-vissza ható folyamat. De e filológiai-módszertani értelmezést az idézet általános szintre tágítja: mindenre ('́gy az élet-egészre) is igaz, hogy az egyedi esemény, történés vagy tett megjelenít 
valamit a tágabb és mögöttes jelentés-összefüggésből, mely utóbbi viszont csak az eseti, egyedi esetek révén értelmezhető. Ezt illusztrálja a 3. ábra.

3. ábra

Megértés: a hermeneutika kör univerzális logikája

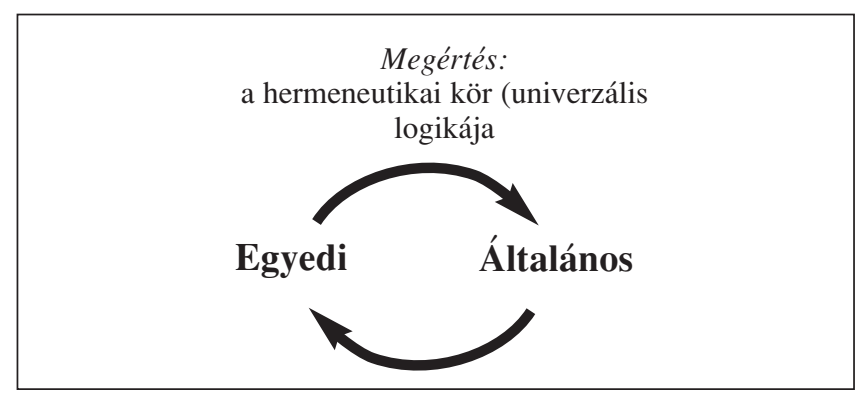

Miért fontos mindez a szervezetek szempontjából?

Felsorolásszerüen és távolról sem kimerítve a témát:

1. Mint mindent, a szervezetet is tekinthetjük egy ,,szöveg"-nek, mely értelmezésre vár és állandóan értelmezik. A szervezet egészének, csakúgy, mint a szervezeten belüli egyes döntéseknek, eseményeknek és tetteknek a hátterében is húzódik mélyebb értelem egy eredendő szándék vagy domináns logika, mely az írott vagy szóbeli közléshez hasonlóan felfejtendő, értelmezendő, bár a teljes megértés soha nem lehetséges.

2. E mögöttes szervezeti értelem vagy logika - mint arról már volt szó - pl. emberi kapcsolatokban és tárgyiasult alkotásokban testesül meg. Példaként gondolhatunk egy értékesítési szabályzatra. Ennek is van „alkotója”, igaz, sokszor már csak a történeti távlatban. Az értékesítési szabályzatba rengeteg - tudatos vagy tudattalan, hivatalos vagy rejtett - eszme, szándék és törekvés épült be megalkotása időszakában, és azóta is. Az akkori közeg (mint jelentéskontextus vagy jelentés-horizont) értelmet adott neki, de az idők folyamán - a kontextus változásával - az eredeti jelentések bizonyára módosultak, a felmerült helyzetek fölülírták az alkotók eredeti célját és szándékát. Ma pedig, az értelmező és újra-értelmező feladatot éppen azok végzik, akik valamiképp kapcsolódnak, viszonyulnak az adott értékesítési szabályzathoz: használják, figyelmen kívül hagyják, bírálják, éppen a megváltoztatásán fáradoznak stb.

3. A gyanú vs. bizalom hermeneutikája kérdéskör is lefordítható a szervezeti gyakorlatra: vegyük például a máshonnan - az alsóbb szintekről, a vezetéstől, a társterülettől stb. - érkező kezdeményezések fogadtatását. A bár kritikus, de befogadó és megérteni vágyó hozzáállás alapvetően más, mint az eleve elutasító, a kezdeményezés mögött mindenképp hatalmi érdeket sejtő (és találó) fogadtatás.

4. Maguk a szervezeti szereplők minden pillanatban értelmeznek, és megértésre törnek. Egyrészt, minden elhatározásuk és tettük már maga is a szervezet és az adott helyzet valamilyen megértését jelenti; a konkrét cselekvés pedig e megértés „szavakba öntése"-ként fogható fel. Másrészt, e tettek maguk is értelmezésre szorulnak. Harmadrészt: ezek az egyedi akciók és tettek - a hermeneutikai kör logikája alapján - maguk is „továbbírják” a szervezet - mint egész - történetét (4. ábra) a szervezetben mindenki olvasó és mindenki szerző is egyben!

\section{4. ábra}

\section{A hermeneutika kör egy alkalmazása a szervezetre}

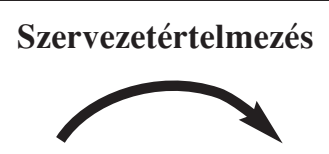

egy adott esemény vagy tett (pl. akció, döntés, konfliktus, ,siker" vagy „kudarc”) jelentése

a szervezet történelme, ,belsô logikája” és „,szellemisége” a realizált stratégia, a közös szervezeti jelentésvilág vagy kultúra

5. A szervezetben az számít adekvát döntésnek és kompetens cselekvésnek, ami összhangban van a szervezettel mint tradícióival, azaz megfelel a ,józan észnek” és a ,hely szellemének”. Ebből szorosan következik, hogy - a vállalati életben uralkodó szemlélettel szemben - a tradíció nem az elavultság szinonimája, hanem - ha értő módon viszonyulunk hozzá - a megújulás valódi forrása:

„A tradíciót nem meghaladni kell, hanem megérteni: ha megtapasztalhatjuk múltunkat, a jövő egyre újabb és újabb lehetőségei tárulnak fel számunkra" (Kockelmans, in: Reason - Rowan, 1981b: 133.).

6. Nem véletlen, hogy a tapasztalt, hiteles és bölcs vezető a „Mit kell tennem?; Mi lenne a helyes döntés ebben a helyzetben?" jellegű kérdéseket sokszor az intuícióira támaszkodva válaszolja meg. Mivel érti a szervezetet, megérti és átérzi a helyzetből fakadó kihívásokat, el tudja választani egymástól a megfelelő és a hibás cselekvési lehetőségeket.

7. Máskor viszont éppen abból származnak a problémák és „meg-nem-értés”, ha a felső vezetés például külső tanácsadók máshol bevált tanácsaira hagyatkozva, vagy a ,,best practice"-t másolva - a szervezeti hagyománytól és kultúrától teljesen idegen - „életidegen” - megoldásokat erőltet át.

8. A ,jó vezető" érzékeny: intézkedéseivel igyekszik kapcsolódni a szervezeti csoportok, helyi gyakorlatközösségek jelentésvilágához, s hacsak nem muszáj, nem kívánja felborítani a kialakult rendet, nem akarja összekuszálni a finom szövedékeket.

9. A külső tanácsadó is csak akkor tud a szervezettel jó kapcsolatba kerülve tényleges segítséget nyújtani, ha - a fenti értelemben vett - megértésre törekszik. Ez azonban nem könnyű. 
10. A kutatói és a tanácsadói szerep lényegét tekintve nem különbözik egymástól: a megértés a feladat. Ez, mint láttuk, önmegértés nélkül nem lehetséges. De le kell mondanunk a teljes megértés illúziójáról is, hiszen ez lehetetlen.

\section{Az interpretatív szervezetközelítés jelentősége}

\section{Az elmélet következményei és értékelése}

Nem meglepő, hogy az interpretatív szervezetvizsgálatok legkedveltebb témakörei például a következők: szervezeti kultúra, szervezeti változás, szervezeti tanulás, innováció és tudás a szervezetben, leadership, szervezeti kommunikáció, szervezet és hatalom; de a szervezeti struktúra vagy a szervezeti kontroll interpretatív elemzéseivel is találkozhatunk (Wollnik, 1995 áttekintését). Azonban vigyázzunk: a fentieket ne egymástól független, diszkrét jelenségekként és változókként kezeljük, sokkal inkább ugyanazon komplex szervezeti valóság különféle olvasataiként vagy megnevezési kísérleteiként.

Az interpretatív szervezetközelítés legfőbb erősségei között Morgan (1995) a következőket említi: 1) ráébreszti a szervezeti szereplőket arra a szerepre, amit a szervezeti valóság alakításában, saját szervezeti környezetük formálásában játszanak, 2) a szervezeti értelmezések és jelentések újradefiniálása révén a szervezeti innováció és változás újszerű lehetőségeit teremti meg, 3) felhívja a figyelmet a szervezeti jelenségek és cselekedetek szimbolikus természetére, 4) a szervezeti valóság folyamat-jellegének hangsúlyozásával oldja a szervezeti valóság „merevségét”, csökkenti „,valódiságát", s ezzel növeli az aktív változtatás esélyét, 5) s ugyanez igaz a „külső” környezetre is, amely ebben a szemléletben nem determinisztikus, hanem sikeresen alakítható és befolyásolható. Mindezt megerősítendő, illetve kiegészítendő, a következő elméleti és/vagy gyakorlati szempontokat tartom még fontosnak:

1. Interpretatív értelemben, erre Morgan is utal, a szervezeti keret felpuhul: a szervezet (újra-) értelmezhetővé, alakíthatóvá, sőt, eredendően is „,alakuló”-vá válik. Az interpretatív szervezetértelmezés a szervezetet tehát nem egy ,egység”-ként, hanem állandóan formálódó és változó folyamatként, „szerveződésként" fogja fel. Erre a folyamatjellegre utal Weick (1979) „organizing” fogalma, illetve Bouwen (1993) „organizing-in-the-making” kifejezése. A vezetés, a szervezetalkotás és a szervezetváltoztatás végső soron e közös, folyamatosan alakuló és formálódó szervezeti valóság definiálásának lehetőségéről szól.

2. A megértés és a dialógus középpontba állításával kiemelten fontossá válik a „másik világ” szempontjainak figyelembevétele, ami - szervezetek tagjaként, szervezetkutatóként vagy szervezeti tanácsadóként is - árnyaltabb, beleérzőbb döntésekre és intézkedésekre sarkall.
3. Az interpretatív szemléletből egyenesen következik, hogy a szervezetben minden kommunikál és minden kommunikáció. A tartalmi szintek mellett, sokszor azokat felülírva, a szimbolikus cselekedetek válnak meghatározóvá. Pontosabban: minden szervezeti esemény, döntés, program vagy akció egyben szimbolikus cselekedet. Minden kommunikál: ez részben a ,küldő" felelőssége. De minden értelmezett is, az értelmezés pedig mindig ,fordítás”: itt merül fel a fogadó (mint tolmács) felelőssége.

4. A valóság társas konstrukciójának elfogadása azt is jelenti, hogy (bár egyénként értelmezéseink és tetteink nem korlátlanul szabadok) személyes és kollektív felelősségünk is van valóságunk konstruálásában.

5. Jóllehet az önreflexió abszolút mértékben sem kulturális, sem pszichológiai értelemben nem érhet a végére (teljes önmegértésre nincs mód), az interpretatív megközelítésben ezzel együtt kiemelt hangsúlyt kap. Az önreflexió kiemelten megjelenik egyrészt a fokozott nyelv-tudatosságban, másrészt az átreflektált személyes élettapasztalatban és előfeltevésekben, illetve az ún. perspektivikus szubjektivitásban (lásd. következő pontot).

6. Interpretatív szempontból újraértékelődik a szubjektivitás fogalma. Objektivitás ugyanis nem lehetséges, csak szubjektivitás létezik! De nem mindegy, milyen minőségű az. Kvale (1996) megkülönbözteti a „,torzító szubjektivitást" (biased subjectivity), amely reflektálatlan, azaz tudatosságot nélkülöző és önigazoló, illetve a ,perspektivikus szubjektivitást" (perspectival subjectivity), amely tudatos önmegértésen alapul és folyamatos önmegkérdőjelezésre épül. Reason (1994) ez utóbbiról szólva kritikai szubjektivitásról beszél, amely tehát más, mint a valóság szubjektív megtapasztalása (elsődleges szubjektivitás), de a valóságtól eltávolodó „objektivitástól” is különbözik:

„A kritikai szubjektivitás annyit jelent, hogy nem nyomjuk el elsődleges szubjektív tapasztalatunkat, hogy belátjuk, hogy tudásunk mindig valamilyen nézőpontból való tudás; de egyben azt is jelenti, hogy tudatában vagyunk saját nézőpontunknak és az ebből fakadó torzításoknak, és kommunikációnkban azt a felszínre hozzuk és megfogalmazzuk. A kritikai szubjektivitás önreflektív figyelem saját személyes hátterünkre" (Reason, 1994: 327.).

Ez utóbbi egy elvállalt, egyben kritikailag reflektált szubjektivitás a megértés pedig részben mindig önmegértés (Sárvári, 1999).

7. Hatalom és retorika szempontjából is új felismerésekhez juthatunk. A nyelv valóságteremtő ereje kapcsán láthattuk, hogy egy szöveg formálása csakúgy, mint értelmezése, hatalmat jelent a szervezetben. 
Ugyanígy, az értelmezési keretek kialakítási lehetősége is hatalomból fakad, és hatalmat teremt. Nem véletlen, hogy a szervezetben jellemzően vagy a dolgok jelentésének definiálása körül zajlik erős harc (pl. „van-e válság, vagy nincs”), vagy akörül, hogy milyen módon, milyen jelentés-kontextusban kerül majd sor az értelmezésre. Nem feledhetjük, hogy a szervezetkutató is hatalmat gyakorol, a kutatási folyamat megtervezésekor és megvalósításakor csakúgy, mint az értelmezésben.

Az interpretatív szervezetközelítés mértékadó kritikája főként a kritikai és a posztmodern szervezetelmélet oldaláról fogalmazódik meg (Alvesson - Deetz, 1996; Alvesson - Willmott, 1996), s ezekhez kapcsolhatók a feminista kritikák is.

A kritikai elmélet például azt kérheti számon az interpretatív elméleten, hogy hiányzik belőle a társadalomkritikai orientáció és az emancipatorikus szándék, s ezzel fenntartja és legitimálja a kialakult társadalmiszervezeti status quot. Bár mindkét megközelítés az emberi identitás, a fennálló társadalmi-szervezeti rend és a létrejövő tárgyi alkotások társas konstrukciójából indul ki, az interpretatív elmélet ezeket természetesnek és szerves módon kialakulónak tartja, míg a kritikai elmélet elnyomónak és ideológiákon alapulónak. Ezt a megközelítésbeli eltérést jól mutatja, hogy míg az interpretatív megközelítés kulcskategóriája a megértés-orientált dialógus, a kritikai közelítés az uralommentes diskurzus lehetőségeit kutatja (Blaikie, 1995; Willmott, 1995; Alvesson - Willmott, 1996).

A posztmodern szerint nem létezik olyan közös és mélyebb jelentés, melyet az interpretatívok feltételeznek, s ezzel a „nagy narratívával” a hamis egység illúzióját táplálják. Emellett az interpretatív alapfogalmat, a „megértés”-t úgy értékelik, mint a másik fél vagy a világ birtokba vételének igényét, s abban alapvető hatalmi motívumot látnak. De a kritikai elmélethez hasonlóan azt is számon kérik az interpretatív szervezetelméleten, hogy nem eléggé érdeklődik a szervezetben marginalizálódó, perifériára nyomott szereplők iránt, mivel nem vizsgálja explicit módon, mely „hangok” szorulnak ki teljesen a szervezeti valóságról szóló diskurzusból (Kvale, 1996 és Grondin, 2002 alapján).

\section{Az alkalmazás fő területe: az interpretatív-kvalitatív szervezetkutatás}

Az interpretatív elmélet magától értetődő alkalmazási területe az interpretatív alapállású kvalitatív szervezetkutatás, melynek kapcsán ehelyütt csak néhány fontosnak vélt szempontot emelek ki.

Ismeretelméleti szempontból az interpretatív paradigma azt hangsúlyozza, hogy a szervezetek a helyi kulturális jelentésvilágon keresztül ismerhetők meg. A szervezetkutatónak ezért közvetlen kapcsolatba kell ke- rülnie a szervezeti valósággal, s minél alaposabban meg kell ismernie a cselekvők szempontjait, az egyedi és kollektív értelmezésmintákat. A kutatás értelemszerúen kitüntetett figyelmet fordít a szervezeti nyelvhasználatra, s kiindulópontját legalább annyira a lokális tudás és nyelv jelenti, mint az előzetes szervezetelméleti összefüggések és koncepciók.

A kutatásban a jelentésmegértés a cél - egyfajta „,belehelyezkedés" a vizsgált szervezet (egyén, csoport, kultúra stb.) helyzetébe, annak átélésére való törekvés, hogy: „Milyen is innen nézve a világ? Mi miről szól és miért? Mi minden számít itt magától értetődőnek?” stb. A feladat a belső, mögöttes szervezeti jelentésvilág feltárása és megértése: a láthatóból eljutni a mögötteshez, a kimondottból következtetni a ki nem mondottra és rejtettre (,,a szavak mögé nézés”, ,a sorok között olvasás”). Azaz: a kvalitatív kutató a tapasztalt konkrétumok (az egyedi) alapján igyekszik következtetni a szervezeti közegre, belső viszonyokra és kultúrára (az általános), illetve fordítva, a szervezeti jelentésvilág (kultúra) egyre jobb megértése révén érti meg egyre mélyebben a konkrét helyzeteket, mondatokat, cselekedeteket és interakciókat is.

Az interpretatív alapállás figyelmeztet, hogy kutatóként mindig értelmezünk, elfogultak vagyunk, és kutatásunkkal értékeket, érdekeket képviselünk. Éppen ezért le kell, mondjunk az értékmentesség hamis illúziójáról. Mivel a kutató is beágyazódott saját tudományos közösségének, társadalmi viszonyainak és személyes múltjának jelentésvilágába, $\mathrm{s}$ a szervezetet csak saját értelmezési kontextusán keresztül tudja tanulmányozni, kiemelt jelentőségű tehát a kutatói szubjektivitás perspektivikus alkalmazása. A kutatási folyamat ilyen értelemben egy „önreflektív dialógust” jelent.

Mivel az interpretatív megközelítés a klasszikus felosztás szerint a szervezetek megértésére és a helyi összefüggések feltárására törekszik, s kevésbé az általános magyarázatra (Morgan - Smircich, 1980; Blaikie, 1995; Wollnik, 1995), előnyben részesíti az egy vagy néhány egyedi esetre épülő mélyelemzést és „sűrű leírás”-t (Geertz, 1994). A helyi jelentésekre és/vagy a feltárt öszszefüggésekre építve azonban a korlátozott általánosítás is lehetséges, ugyanakkor nem lehet cél a helyi kontextustól független, általános magyarázatok - a ,nagy elméletek" - elóállítása, vagy az előzetesen létező elméletek tesztelése (Smircich - Morgan, 1982; Blaikie, 1995; Wollnik, 1995). A célok között az elmélet-építés sokkal inkább mint „grounded theory” létrehozás szerepelhet (magyarul pl. Bokor, 2003).

$\mathrm{Az}$, hogy végül az empirikus kutatás egyedi esetek sűrű leírását jelenti-e, vagy a mély megértés mellett/ helyett valamilyen mértékben oksági összefüggéseket is igyekszik feltárni, a szervezetkutató valóságképétől függ (azaz, hogy milyen mértékben áll ,szubjektivista” alapokon). Ez tükröződik abban is, hogy döntően a helyi fogalmakra és a lokális tudásra támaszkodik-e (naturalisztikus 
Mit jelent a kvalitatív kutatás? - tudományfilozófiai alapállás és alkalmazott kutatási eszközök különbsége (saját rendszerezés)

\begin{tabular}{|c|c|c|}
\hline & $\begin{array}{l}\text { Hagyományos (pozitivista) alapállás } \\
\text { (tudományfilozófia és módszertan) }\end{array}$ & $\begin{array}{l}\text { Interpretatív-kvalitatív alapállás } \\
\text { (tudományfilozófia és módszertan) }\end{array}$ \\
\hline $\begin{array}{l}\text { Kvantitatív kutatási } \\
\text { eszközök }\end{array}$ & $\begin{array}{l}\text { - kontrollált (laboratóriumi) kísérletek } \\
\text { - kvázi-kontrollált kísérletek } \\
\text { - kérdőív: nagymintás adatgyűjtés és elemzés }\end{array}$ & $\begin{array}{l}\text { - kérdőív: nyitott kérdések } \\
\text { - kérdőívek, mint a kultúra tárgyiasult megnyilvánulá- } \\
\text { sai }\end{array}$ \\
\hline $\begin{array}{l}\text { Kvalitatív kutatási } \\
\text { eszközök }\end{array}$ & $\begin{array}{l}\text { - strukturált interjú } \\
\text { - félig strukturált interjú és tartalomelemzés } \\
\text { - fókusz-csoport és tartalomelemzés } \\
\text { - dokumentumok tartalomelemzése }\end{array}$ & $\begin{array}{l}\text { - kvalitatív interjú (strukturálatlan ill. félig-strukturált } \\
\text { interjú és megértő elemzés } \\
\text { - résztvevő megfigyelés } \\
\text { - fókusz-csoport és megértő elemzés } \\
\text { - dokumentum-elemzés } \\
\text { - tárgyak, terek, szimbólumok elemzése } \\
\text { - kognitív térképek } \\
\text { - napló-készítés, vizuális technikák } \\
\text { - akciókutatás }\end{array}$ \\
\hline
\end{tabular}

irányzat), vagy alkalmaz előzetes elméleti-fogalmi koncepciókat (erről lásd: Hammersly - Atkinson, 1994). A különféle elméleti megközelítésekben és a megvalósuló kutatói gyakorlatban sokszor vegyes megoldásokkal találkozhatunk, s ugyanez igaz az alkalmazott módszerekre is, bár a kvalitatív technikák alkalmazása döntő.

Az interpretatív kutatási filozófiát és metodológiát a kvalitatív kutatási irányzat részének tekinthetjük (Taylor - Bogdan, 1984; Denzin - Lincoln, 1994). Ez számos eltérő kutatási megközelítés gyűjtőkategóriája, keretein belül rengeteg különböző kutatási módszer és technika kerül alkalmazásra (Denzin - Lincoln, 1994; a kvalitatív szervezet-kutatásokról Cassell - Symon, 1994). Az interpretatív alapállás jelenti a biztosítékot ahhoz, hogy ténylegesen - a kutatás alapelveit tekintve is - kvalitatív kutatásról beszélhessünk: interpretatív-kvalitatív filozófiájú, kvalitatív módszertanú, a kvalitatív kutatási eszközöket kvalitatív módon alkalmazó szervezetkutatásról! Hiszen sokszor látjuk, hogy bár az adatgyűjtési eszközök során a kutató „,kvalitatív” eszközöket használ, alapállása és a kutatás felépítése pozitivista. A 3. táblázat két szempontból, kutatási filozófia és kutatási eszközök oldaláról is értelmezi a kvalitatív kutatást.

Mint látható, az interpretatív megközelítés a kvalitatív szervezetkutatás egyik legfontosabb kutatás-filozófiai és szervezetelméleti háttere. De a korábbiakból kiderült, hogy ennél sokkal többet jelent. Egy alapvető világlátást, a szervezethez, valósághoz és önmagunkhoz való megváltozott viszonyt. Véleményem szerint azt is, hogy a valóban fontos kérdésekkel foglalkozunk, no és iránymutatást, távlatokat ahhoz, hogy a helyes válaszok felé haladjunk. De jelenti annak bizonyosságát is, hogy a végső megértéshez soha nem juthatunk el.

\section{Felhasznált irodalom}

Alvesson, M. - Deetz, S. (1996): A munkahelyi uralom modern formái (eredetileg: Critical theory and postmodernism approaches to organization studies). In: Clegg, S. R. - Hardy, C. - Nord, W. R. (eds.) (1996): Handbook of organization studies. Sage, London. pp.191-217
Alvesson, M. - Willmott, H. (1996): Making sense of management. A critical introduction. Sage, London

Anzenbacher, A. (1994): Bevezetés a filozófiába. Herder, Budapest

Astley, W. G. - Van de Ven, A. H. (1983): Central perspectives and debates in organization theory. Administrative Science Quarterly, Vol. 28, pp. 245-273

Astley, W. G. - Zammuto, R. F. (1992): Organization science, managers, and language games. Organization Science, Vol. 3., no. 4. pp. 443-460

Bakos Ferenc (1983) (szerk): Idegen szavak és kifejezések szótára. 6. kiadás. Akadémiai Kiadó, Budapest

Berger, P. - Luckman, T. (1998): A valóság társadalmi felépítése. Tudásszociológiai értekezés. 1998, Jószöveg, Budapest

Blaikie, N. (1995): Approaches to social enquiry. Polity Press, Cambridge

Bokor A. (1994): Posztmodern a menedzsmenttudományban. Közgazdasági Szemle, 16. évf., 12. sz. pp. 1118-1132

Bokor A. (2003): A szervezeti kultúra hatása a termékfejlesztés folyamatára. Vezetéstudomány, 34. évf. 10. sz., pp. 37-56

Bougon, M. G. (1992): Congregate cognitive maps: A unified dynamic theory of organization and strategy. Journal of Management Studies, Vol. 29, no. 3, pp. 370-389

Bouwen, R. (1993): Inquiry and intervention for development in change and innovation contexts: a 'learning' methodology from a social constructionist perspective. University of Canterbury

Bouwen, R. - Steyaert, C. (1995): From dominant frames toward multi-voiced cooperation: Mediating metaphors for global change. Paper prepared for the Academy of Management Joint Divisional Conference on 'The Organization Dimensions of Global Change: No limits to cooperation', May 3-5, 1995, Case Western Reserve University, Cleveland, Ohio

Brown, J. S. - Duguid, P. (1991): Organizational learning and communities-of-practice: toward a unified view of working, learning and innovation. Organization Science, Vol 2, no 1. pp. 40-57

Burrell, G. - Morgan, G. (1979): Sociological paradigms and organizational analysis. Heinemann Educational Books, London

Cassell, C. - Symon, G. (eds.) (1994): Qualitative methods in organizational research. A practical guide. Sage, London

Checkland, P. (1990): Systems thinking, systems practice. John Wiley and Sons

Child, J. (1972): Organizational structure, environment and performance: The role of strategic choice. Sociology, No. 1

Denzin, N. K. - Lincoln, Y. S. (eds.) (1994): Handbook of qualitative research. Sage, Thousand Oaks, California

Dobák M. et all., (1996): Szervezeti formák és vezetés. KJK, Bp.

Drótos Gy. (1999): Az információrendszerek perspektívái. PhD értekezés. BKÁE Vezetési és Szervezési Tanszék, Budapest

Eden, C. (1992): On the nature of cognitive maps. Journal of Management Studies, Vol. 29, no 3., pp. 261-265.

Engeström, Y. (2000): Comment on Blackler et al. Activity theory 
and the social construction of knowledge: A story of four umpires. Organization, Vol. 7, no. 2, pp. 301-310.

Gadamer, H. G. (2003): Igazság és módszer. Egy filozófiai hermeneutika vázlata. 2. kiadás. Osiris, Budapest

Gagliardi, P. (ed.) (1990): Symbols and artifacts: views of the corporate landscape. Aldine de Gruyter, Berlin

Geertz, C. (1994): Sűrű leírás. In: Az értelmezés hatalma. Századvég, Budapest (eredeti: The interpretation of cultures., 1973, Basic Books, New York)

Gelei A. (1996): Szervezeti keret és szervezeti változás - egy értelmezési kísérlet. Szociológiai Szemle, 1996. 3-4 sz., 55 - 81. o.

Gelei, A. (2002): A szervezeti tanulás interpretatív megközelítése: a szervezetfejlesztés esete. PhD értekezés, BKÁE, Gazdálkodástani $\mathrm{PhD}$ Program, Budapest

Gherardi, S. - Nicolini, D. (2000): To transfer is to transform: the circulation of safety knowledge. Organization, Vol. 7, no. 2, pp 329-348.

Gioia, D. A. - Pitre, E. (1990): Multiparadigm perspectives on theory building. Academy of Management Review, Vol. 15., no. 4., pp. 584-602.

Granovetter, M. (1990): A gazdasági intézmények társadalmi megformálása: a beágyazottság problémája. (angolul: The old and the new economic sociology: a history and an agenda. In: Friedland, R. - Robertson, A. F. (eds.): Beyond the marketplace: rethinking economy and society. Aldine de Gruyter, New York. pp. 95-112.

Grondin, J. (2002): Bevezetés a filozófiai hermeneutikába. Osiris Kiadó, Budapest

Hammersly, M. - Atkinson, P. (1994): Chapter 1: What is ethnography? In: Ethnography: principles in practice. (4th ed.) Tavistock, London

Kieser, A. (szerk.) (1995): Szervezetelméletek. Aula, Budapest

Kieser, A. (2002): Konstruktivista megközelítések. Ford. Lazányi Kornélia, és Tirnitz Tamás; szakmai szerk.: Kovács Sándor. Kézirat, BKÁE Vezetési és Szervezési Tanszék

Kieser, A. (1996): Rhetoric and Myth in Management Fashion. Kézirat, University of Mannheim

Kindler J. (1980): A pozitivista módszertan válsága. Világosság, augusztus-szeptember, pp. 484-493.

Kindler J. (1989): A komplexitás törvényszerűségei és néhány gyakorlati következményük. In: Kovács S. (szerk.): Szöveggyűjtemény a szervezetelmélet történetének tanulmányozásához. Kézirat. 4. kiadás. Tankönyvkiadó, Budapest.

Kovács S. (1990): Szempontok az elméleti irányok megítéléséhez. In: Kovács S. (szerk.): Szöveggyűjtemény a szervezetelmélet történetének tanulmányozásához. Kézirat. 4. kiadás. Tankönyvkiadó, Budapest

Kuhn, T. (1984): A tudományos forradalmak szerkezete. Gondolat, Budapest

Kvale, S. (1996): InterViews. An introduction to qualitative research interviewing. Sage, Thousand Oaks, California

Morgan, G. (1986): Images of organization. Beverly Hills, CA: Sage

Morgan, G. (1995): Paradigm diversity in organizational research In: Hassard, J. és Pym, D. (eds.) (1995): The theory and philosophy of organizations. Routledge, London

Morgan, G. - Smircich, L. (1980): The case for qualitative research Academy of Management Review. Vol. 5, no. 4, pp. 491-500.

Orton, J. D. (2000): Enactment, sensemaking and decision making: redesign processes in the 1976 reorganization of US Intelligence. Journal of Management Studies, Vol. 37, no 2, pp. 213-234.

Radácsi, L. (2003): „One best way” a menedzsmenttudományos kutatásokban. Gondolatok a kvalitatív módszertan hazai helyzete ürügyén. Vezetéstudomány, 34. évf., 10. sz., pp. 4-12.

Reason, P. (1994): Three approaches to participative inquiry. In: Denzin, N.K. és Lincoln, Y.S. (1994): Handbook of qualitative research. Sage, Thousand Oaks, California

Reason, P. - Rowan, J. (eds) (1981): Human inquiry. A sourcebook of new paradigm research. John Wiley and Sons, Chichester

Risberg, A. (1999): Ambiguities thereafter. An interpretive approach to acquisitions. Lund University Press, Lund
Ropolyi L. (2000): A tudomány a „szociális-élet-világban”. A tudományfilozófia hermeneutikai és szociálkonstruktivista szemléletmódjainak összevetése. Replika, 41-42. sz., pp.125-138.

Romani, L. - Topс̧u, K. - Primecz, H. (2005): The Kulturstandard method. A venue for paradigm interplay in cross-cultural management. Kézirat. Tanulmány az EGOS 21-ik kollokviumára

Sárvári Gy. (1999): Metalépés. Hermeneutika - mélylélektan - rendszerszemlélet: integratív paradigma a tapasztalati tanulás értelmezési-megértési folyamatához. Animula, Budapest

Schein, E. H. (1992): Organizational culture and leadership. 2nd. ed. Jossey-Bass Publishers, San Francisco

Schein, E. H. (1994): On dialogue, culture, and organizational learning. Organizational Dynamics special issue: The learning organization in action. Organizational Dynamics

Scherer, A. G. (2002): Szervezetkritika vagy szervezett kritika? Tudományelméleti megjegyzések a szervezetelméletek kritikus alkalmazásához. Kézirat. Ford. Lazányi Kornélia, és Tirnitz Tamás. BKÁE Vezetési és Szervezési Tanszék

Schulz, M. - Hatch, M. J. (1996): Living with multiple paradigms: The case of paradigm interplay in organizational culture studies. Academy of Management Review, Vol. 21, no. 2, 529-557.

Sievers, B. (1990): Curing the monster: Some images of and considerations about the Dragon. In: Gagliardi (ed): Symbols and Artifacts. Views of the corporate landscape. De Gruyter, New York

Sims, Jr. H. P. - Gioia, D. A. (eds.) (1986): The thinking organization: Dynamics of organizational social cognition. Jossey-Bass Publishers, San Francisco

Smircich, L. (1983 a): Concepts of culture and organizational analysis. Administrative Science Quarterly, Vol. 28. pp.339-358.

Smircich, L. (1983 b): Organizations as shared meanings. In: Pondy, L. R. et al.: Organizational Symbolism, pp. 55-66

Smircich, L. - Morgan, G. (1982): Leadership: the management of meaning. The Journal of Applied Behavioral Science Vol. 18, no 3, pp. 257-273.

Taylor, S. T. - Bogdan, R. (1984): Introduction to qualitative research methods. The search for meaning. (2nd ed.) John Wiley and Sons, New York

Walgenbach, P. (1996): Intézményi megközelítések a szervezetelméletben. Kézirat. Ford.: Lázár László. BKÁE Vezetési és Szervezési Tanszék

Watzlawick, P. - Weakland, H. H. - Fisch, R. (1974): Change. Principles of problem formation and problem resolution. W. W. Norton \& Company, New York

Weick, K. (1979): The social psychology of organizing. (2nd ed.) Reading, MA: Addison-Wesley

Weick, K. E. (1983): Managerial thought in the context of action. In: Srivastva, S. (ed.) The executive mind. Jossey-Bass Publishers, San Francisco

Weick, K. E. - Westley, F. (1996): Organizational learning: Affirming an oxymoron. In: Clegg, S. R. - Hardy, C. - Nord, W. R. (eds.) (1996): Handbook of organization studies. Sage, London. pp. 440-458.

Weisinger, J. Y. - Salipante, P. F. (n. a.): Inquiring into cross-cultural knowledge: Challenging cognitive conceptions of culture. Kézirat. Case Western Reserve University, Cleveland, Ohio

Willmott, H. (1995): Beyond paradigmatic closure in organizational enquiry. In: Hassard, J. - Pym, D. (eds.) (1995): The theory and philosophy of organizations. Routledge, London

Winch, P. (1958): The idea of a social science and its relation to philosophy. Routledge \& Kegan Paul, London

Wollnik, M. (1995): Interpretatív megközelítések a szervezetelméletben. In: Kieser, A. (szerk.) (1995): Szervezetelméletek. Aula, Budapest

Yanow, D. (2000): Seeing organizational learning: A "Cultural" view. Organization. Vol. 7, no. 2, pp. 247-258

\section{Lábjegyzetek}

A „Szervezetelméletek” című kurzusokat Kovács Sándor professzor teremtette meg a „Közgázon”, s így a mai Budapesti Corvinus 
Egyetemen, de bátran kijelenthető, hogy az egész hazai közgazdasági - gazdálkodástudományi felsőoktatásban is.

2 ,...using 'superintelectual theory' to practical work, like academic research, organizational consultancy and action research" Robert French, angol szervezetelméleti szakember és tanácsadó megfogalmazása (személyes beszélgetés, 2006).

${ }^{3}$ E tanulmány alapanyagát doktori disszertációm elméleti része jelenti (Gelei, 2002), illetve a Szervezetelméletek kurzusokon e témában tartott előadásaim.

${ }^{4}$ Az alkotói szabadság sem azt jelenti, hogy a művész kénye-kedve szerint bármit alkothat (vö. Gadamer, 2003)

${ }^{5}$ A paradigmák szervezetelméleti szerepét nagy hatású művükben legelőször Burrell és Morgan (1979) fogalmazták meg, de fontos Astley és Van de Ven (1983) tanulmánya, illetve Morgan (1986) könyve a metaforák szervezeti szerepéről. A szervezeti struktúra eltérő jelentéseiről lásd pl. Gioia-Pitre (1990); az információrendszerek különféle perspektíváiról Drótos (1999), míg a szervezeti kultúra esetében Smircich (1983), ill. Schultz-Hatch (1996) műveit. Német nyelvterületen például Kieser (1995), míg hazánkban Kindler József (1980) és Kovács Sándor (1990) mutatott rá a szervezetelméletek különbözőségeire és paradigmafüggőségére.

${ }^{6} \mathrm{Az}$ eredeti mátrix a nagy szellemi áramlatokat igen árnyaltan, egymásba kapcsolódó „felhőkként” mutatja be, melyek átívelik a paradigma-határokat. A paradigmák összemérhetetlenségének (inkommenzurabilitásának) problematikájáról bővebben lásd Scherer (2002) elemzését, a megoldási lehetőségekről pedig pl. Romani - Topçu - Primecz (2005) összefoglalását.

7 Blaikie (1995) szűkebb értelemben Weber „,megértő szociológiáját", Schütz interpretatív megközelítését és Winch nyelvfilozófiáját sorolja az interpretatív megközelítések közé, de a hagyomány ennél tágabb. Felsorolásképp, de a teljesség igénye nélkül, a szellemi gyökerek között megtalálható a megértő vagy interpretatív szociológia (Weber, G.H. Mead, Blumer, Schütz, Berger és Luckmann, Giddens) és az etnometodológia (Garfinkel), az inter- pretatív antropológia (Geertz), a pszichológia fenomenológiai (Rogers, Maslow, Kelly) és palo altoi (Watzlawick) iskolái, a filozófiában a fenomenológia (pl. Husserl, Merleau-Ponty, Schütz) és a hermeneutika (pl. Schleiermacher, Dilthey, Heidegger, Gadamer, Ricoer) különféle irányzatai, de távolabbról Wittgenstein vagy Habermas is köthető. Az ún. interpretatív vagy „,puha” rendszerelmélet kapcsán kiemelendő Checkland; a konstruktivizmus képviselői között pedig pl. Latour, Gergen vagy von Glasersfeld (Schwandt, 1999; Wollnik, 1995; Kieser, 2002; a filozófiai alapokról pl.: Anzenbacher, 1994; Störig, 1997).

${ }^{8}$ Meg kell különböztetnünk az értelmezési sémát, mint „keretet” (a nyelvben erre utal a ,szintaktika” fogalom) és magát a jelentést, az értelmezés ,tartalmát” (a nyelvben: „szemantika”). A közös értelmezési séma kialakulása még nem vezet szükségszerúen azonos jelentéstartalmakhoz, ,....inkább egy közös platform teremtésére szolgál, amelyhez később specifikus definíciós folyamatok kapcsolódnak, és amelyekre támaszkodva speciális jelentésminták konstruálhatók" (Wollnik, in: Kieser, 1995:368.).

9 Yanow (2000) ilyen értelemben tesz különbséget a kultúra tárgyi alkotásainak „konstruktív” (hermeneutikai), illetve „szimbolikus” jelentése között.

${ }^{10}$ Hiszen lássuk be, magát a kérdést, hogy „Foglya vagyok-e saját nyelvemnek?" sem tudjuk másképp, csak nyelvileg elgondolni. Grondin (2002) ezzel együtt kimutatja, hogy nem vagyunk rabjai saját nyelvünknek, mivel tudatosság és reflexió révén távolságot tudunk tartani saját nyelvhasználatunktól, illetve választani tudunk, mit hogyan tudnánk leghelyesebben kifejezni. De vajon van-e a szervezetekben elég nyitottság és bátorság arra, hogy kritikusan szembenézzenek avval, a legmélyebb szinteken mi mindenről is árulkodik a szervezeti nyelvhasználat és a belső zsargon? ${ }^{11} \mathrm{Ez}$ a dilemma egy szervezeten belül felmerülhet az eltérő funkcionális területek, a különböző hierarchiaszintek vagy a különféle szakma-kultúrák között (Schein, 1994) csakúgy, mint pl. a szervezetkutatók és a menedzserek viszonylatában (Astley - Zammuto, 1992) 